The published manuscript is available at EurekaSelect via

http://www.eurekaselect.com/openurl/content.php?genre=article \&doi=10.21

$\underline{74 / 1381612821666151002113546}$

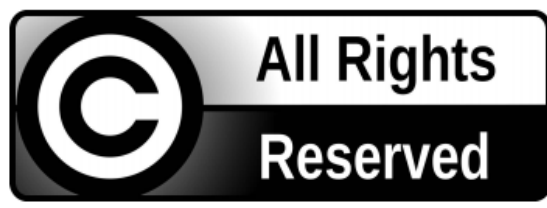

(C) Bentham Science Publishers 


\title{
Title: New Approaches with Natural Product Drugs for Overcoming Multidrug Resistance in Cancer
}

\author{
Short running title: Natural Products and Cancer MDR \\ Jelena Dinić*, Ana Podolski-Renić, Tijana Stanković, Jasna Banković and Milica Pešić* \\ University of Belgrade, Institute for Biological Research "Siniša Stanković", Department of Neurobiology, \\ Despota Stefana 142, 11060 Belgrade, Serbia
}

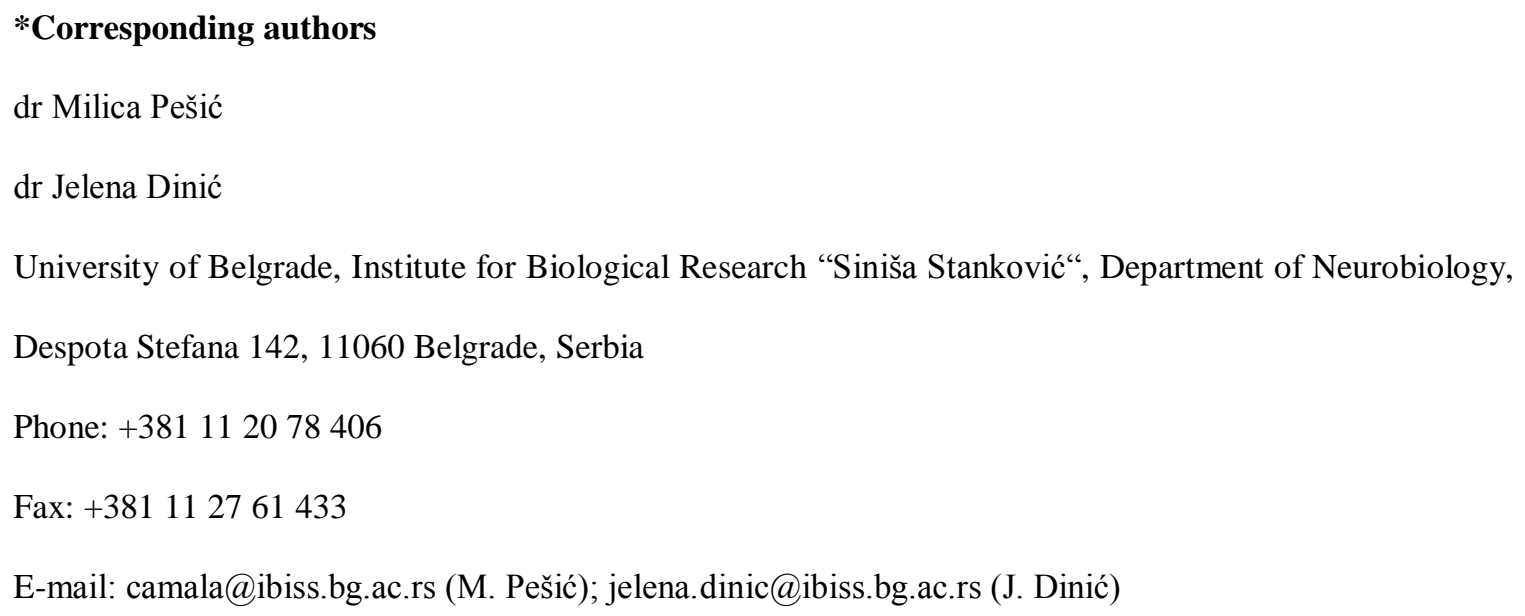




\title{
New Approaches with Natural Product Drugs for Overcoming Multidrug Resistance in Cancer
}

Jelena Dinić*, Ana Podolski-Renić, Tijana Stanković, Jasna Banković and Milica Pešić*

University of Belgrade, Institute for Biological Research "Siniša Stanković", Despota Stefana 142, 11060

Belgrade, Serbia

\begin{abstract}
:
Resistance to chemotherapeautic drugs is one of the main obstacles to effective cancer treatment. Multidrug resistance (MDR) is defined as resistance to structurally and/or functionally unrelated drugs, and has been extensively investigated for the last three decades. There are two types of MDR: intrinsic and acquired. Tumor microenvironment selection pressure leads to the development of intrinsic MDR, while acquired resistance is a consequence of the administered chemotherapy. A central issue in chemotherapy failuire is the existance of heterogeneous populations of cancer cells within one patient and patient-topatient variability within each type of cancer.

Numerous genes and pathways contribute to the development of MDR in cancer. Point mutations, gene amplification or other genetic or epigenetic changes all affect biological functions and may lead to the occurrence of MDR phenotype. Similar to the characteristics of cancerogenesis, the main features of MDR include abnormal tumor vasculature, regions of hypoxia, aerobic glycolysis, and a lower susceptibility to apoptosis. In order to achieve a lethal effect on cancer cells, drugs need to reach their intracellular target molecules. The overexpression of the efflux transporter P-glycoprotein (P-gp) in MDR cancer cells leads to decreased uptake of the drug and intracellular drug accumulation, minimising drug-target interactions.

New agents being or inspired by natural products that sucessfully target these mechanisms are the main subject of this review. Two key approaches in combating MDR in cancer are discussed (i) finding agents that preserve citotoxicity toward MDR cancer cells; (ii) developing compounds that restore the cytotoxic activity of classic anticancer drugs.
\end{abstract}

Keywords: Cancer, multidrug resistance, P-glycoprotein, natural product drugs, plant secondary metabolites, marine products. 


\section{INTRODUCTION}

Resistance to anticancer agents is mediated by multiple mechanisms including reduced apoptosis, decreased drug uptake via transporters, altered drug metabolism or site of action, increased DNA damage repair or energy dependent efflux of free-diffusing hydrophobic anticancer agents.

Multidrug resistance (MDR) develops when cancer cells become gradually insensitive to structurally dissimilar drugs and represents a major impediment to the successful cancer treatment. One of the key mechanisms regulating MDR is extensive production of P-glycoprotein (P-gp), a transmembrane efflux pump encoded by the $m d r l$ gene [1-2]. Overexpression of P-gp is linked to both intrinsic and acquired drug resistance and has become a major therapeutic target in tumors with MDR phenotype.

P-gp is generally expressed in tissues such as liver, kidney, and gastrointestinal tract, where it contributes to elimination of potentially harmful substances from the cell [3]. In addition to P-gp, many other transporters belong to the same class referred to as ATP Binding Cassette (ABC) transporters. These transporters use energy from ATP hydrolysis to actively export components like amino acids, bile acids and hormones out of the cell [4]. The superfamily of $A B C$ transporters includes seven subfamilies based on their sequence homology and domain organization. Anticancer therapy is mainly affected by three efflux pumps: P-gp (MDR1 or ABCB1), multidrug resistance associated protein 1 (MRP1 or ABCC1) and breast resistance protein (BCRP or ABCG2) [4] (Fig. 1). These transporters are responsible for traffic of numerous anticancer drugs including vinca alkaloids, anthracyclines, mitoxantrone, paclitaxel, etoposide and tyrosine kinase inhibitors (gleevec and nilotinib) [5]. 

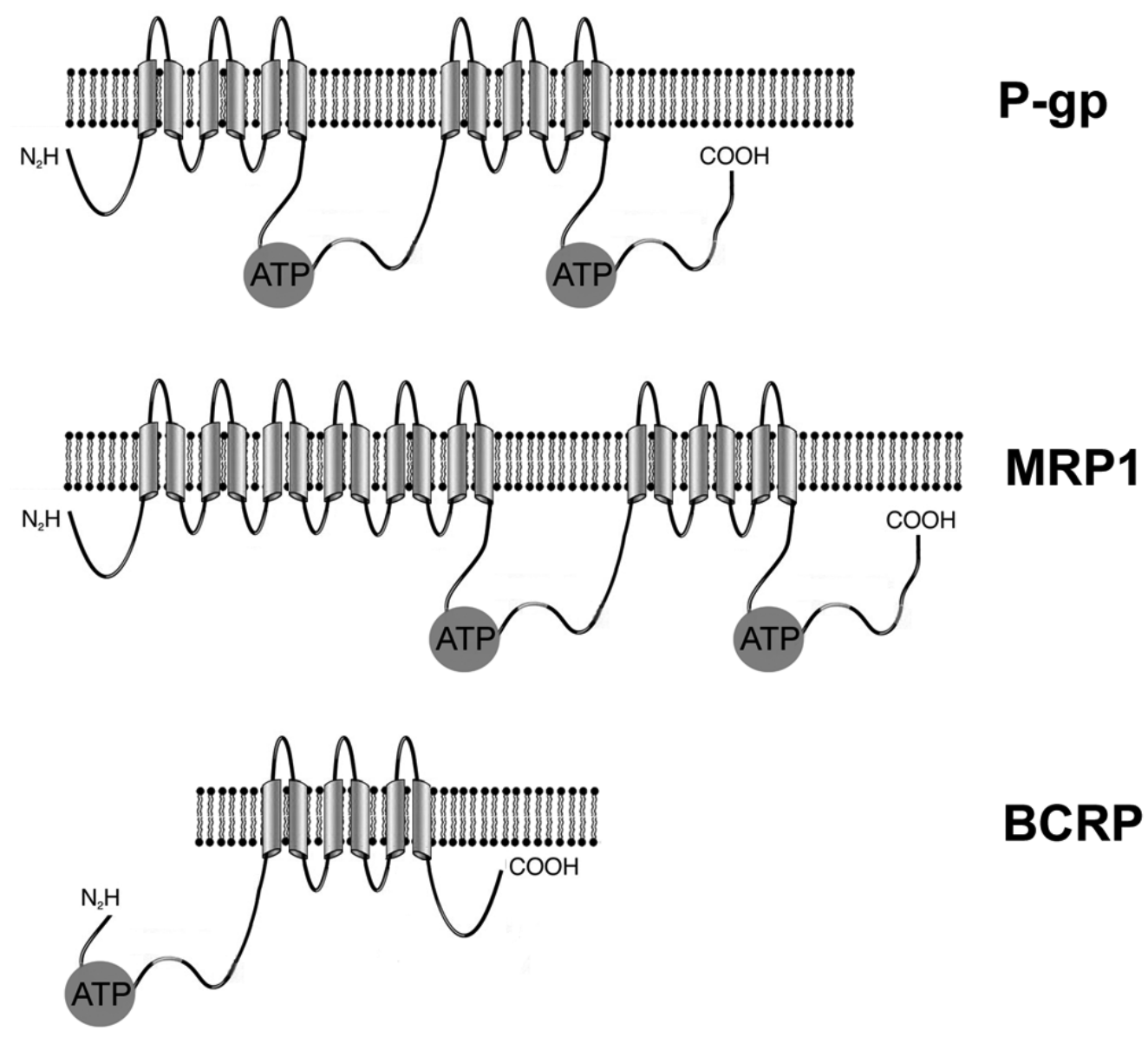

\section{BCRP}

Fig. (1). Membrane topology models of P-gp (MDR1/ ABCB1), MRP1 (ABCC1) and BCRP (MXR/ABCG2) proteins. $\mathrm{ABC}$ transporters consist of multiple transmembrane domains, which anchor the transporter into a lipid bilayer, and ATP-binding cassettes that bind two ATP molecules which are hydrolyzed to provide the energy for substrate translocation out of the cell or a cellular compartment.

Expression of efflux pumps in tissues in non-physiological manner may greatly influence absorption, elimination, distribution, metabolism, and toxicity of drugs [6]. Consequently, finding new methods for suppression of these transporters is crucial for restoring drug sensitivity and enhancing the effectiveness of anticancer therapy [7-9]. 
Finding an inhibitor with suitable specificity, effectiveness and intrinsic toxicity is very difficult considering that major $\mathrm{ABC}$ drug transporters overlap in substrate specificities and show variability in expression levels and polymorphisms. Moreover, interactions of transporter modulators with other anticancer drugs may lead to nonspecific side effects, which make overcoming of MDR exceptionally complex.

Numerous approaches are employed to overcome MDR including competitive, noncompetitive and allosteric blocking of the drug binding sites on P-gp, or the inhibition of ATP hydrolysis and the modification of membrane lipids [10-11].

A variety of agents are being developed to evade P-gp activity. There are multiple compounds that are not P-gp substrates which could potentially serve as anticancer agents [12-13]. These compounds which possess various structures and mechanisms of action include microtubule stabilizing (epothilones, new taxanes) and destabilizing agents (cryptophycins, halichondrins), as well as inhibitors of topoisomerase I and II. Many of these compounds possess very similar structure as P-gp substrates; however structural alterations at specific sites permit them to overcome MDR.

Discovering a selective, effective and fairly non-toxic compound, that inhibits $\mathrm{ABC}$ transporters and re-establishes drug sensitivity in tumors with MDR phenotype, is a key challenge in cancer treatment. For centuries, natural products (often also referred to as secondary metabolites) originating from plants, animals, and microorganisms have been employed to treat various diseases. Many active ingredients found in natural sources are extensively studied to develop effective drug treatments. Even though synthetic drugs are generally easier to produce, the majority of the world's population still largely utilizes traditional herbal medicines [14].

For over 40 years, compounds derived from natural products have been increasingly used as chemopreventive agents as well as in cancer therapy [15]. Podophyllotoxin, isolated from Podophyllum peltatum in 1947, was the first natural compound utilized for its anticancer activity. Since then, numerous small organic molecules derived naturally from microbes and plants have led to development of useful cancer chemotherapeutic drugs. Today, secondary metabolites and their derivatives represent the majority of the approved candidates for anticancer drugs developed in the last three decades [16]. The search for 
new naturally occurring anticancer lead compounds is still ongoing, with the increasing focus on marine fauna and flora, as well as components found in terrestrial microorganisms.

This review highlights the most investigated groups of natural products, their chemistry, diverse structure, and anticancer activity, especially regarding to their effect in overcoming MDR phenotype in tumors.

\section{MDR MODULATORS FROM NATURAL SOURCES}

Modulators and inhibitors of $\mathrm{ABC}$ transporters originating from natural products belong to fourth generation of inhibitors. In recent years, screening for new natural product modulators draws a lot of attention, as many of them possess lower toxicity and higher efficiency than numerous earlier generation modulators. Biologically active compounds derive from a variety of sources including plants, fungi and marine organisms. Large number of studies is aimed to find candidates from natural extracts, which strongly modulate the function or the expression of $\mathrm{ABC}$ drug transporters [17] (Fig. 2). Following purification, characterization, and structure-activity relationship studies, a number of the lead compounds were identified and many of them were modified to optimize the effectiveness. For instance, fumitremorgin $\mathrm{C}$, a fungal toxin, is shown to be a very efficient ABCG2 inhibitor but it is highly neurotoxic [18]. Therefore, a less toxic analog was generated that displays higher potency and specificity Ko143, making it more appropriate for clinical trials [19]. 


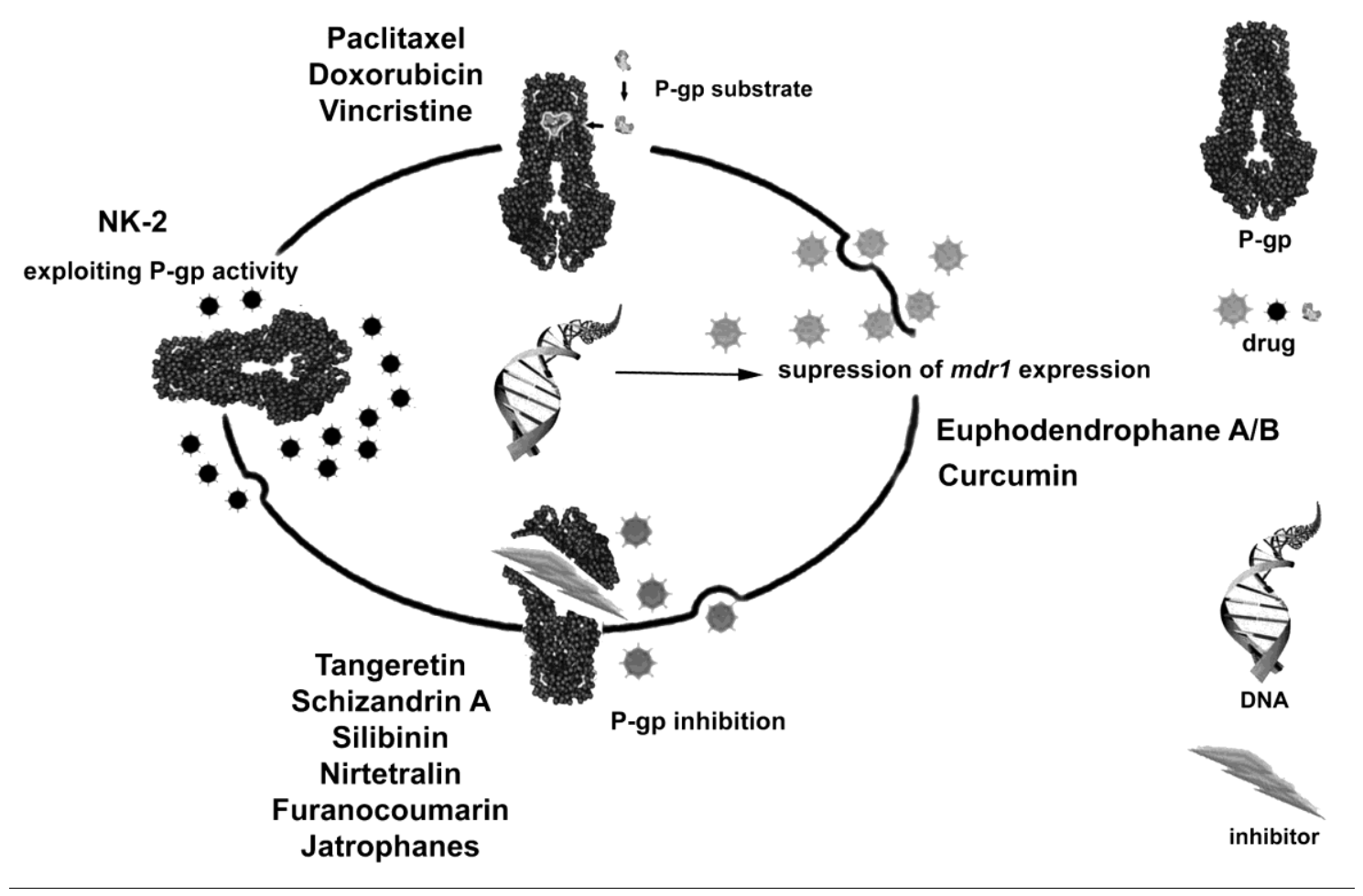

Fig. (2). Examples of biologically active compounds from natural sources and their interaction with the Pgp transporter. Natural products interact with P-gp as substrates (paclitaxel), inhibitors (jatrophanes), suppressors of $m d r l$ expression (curcumin) or they can exploit the presence of P-gp and preferentially kill P-gp high-expressing cancer cells (NK-2).

\section{PLANT SECONDARY METABOLITES}

Plant secondary metabolites are biosynthetically derived from primary metabolites (such as carbohydrates, lipids, amino acids, acetyl-CoA) and are not directly engaged in the growth, development, or reproduction of plants. Although their chemical structures substantially differ, the secondary metabolites are classified into several major groups including phenolics, terpenoids and alkaloids.

\section{PHENOLIC COMPOUNDS}

The main characteristic of phenolic compounds is the absence of nitrogen atoms and the presence of at least one aromatic ring with one or more hydroxyl groups attached [20]. Phenolics are frequently 
found conjugated to sugars and organic acids. Most plentiful polyphenols found in plants include phenolic acids, flavonoids, stilbenes, and lignans.

Flavonoids are phenolic compounds that often possess phenylchromanone structure (C6-C3-C6) and display wide range of biological activities including antimitotic, antiviral and anticancer properties [2123]. They are also reported to display kinase inhibiting [24], radical scavenging, and metal ion chelating activity [25]. Based on the different levels of oxidation of the central $\mathrm{C}$ ring, patterns of hydroxylation and substitutions in their heterocyclic ring, the most important groups of flavonoids are classified into flavonols, flavones, flavanones, isoflavones, flavanols, chalcones, and anthocyanidins. Sugars and hydroxyl groups increase the water solubility of flavonoids while other substituents, like methyl and isopentyl groups, make them lipophilic [26]. Structural modifications such as hydroxylation, methylation, and glycosylation can greatly affect the solubility and bioavailability of flavonoids and influence their anticancer activity as a result. Flavonoids can competitively bind to substrate-binding sites [27-28], affect ATP binding or hydrolysis at the nucleotide binding domains, or alter the surface expression levels of $\mathrm{ABC}$ transporters [29].

Quercetin is among most widely spread flavonoids [30] and it is mainly found in black and green teas, apple, strawberry, onion, broccoli, and kale [31]. Quercetin has been recognized as a strong antioxidant, anti-inflammatory and vasodilating agent that may inhibit almost all stages of cancer development. This flavonoid directly targets activity of different protein kinases important for the process of carcinogenesis [32-34]. Reports have shown that quercetin inhibits $\beta$-catenin nuclear translocation and consequent downregulation of $\beta$-catenin dependent transcription, thus antagonizing the $\mathrm{Wnt} / \beta$-catenin signaling pathway in teratocarcinoma NT2/D1cells [35]. In addition, quercetin restores drug sensitivity of MDR tumor cells through modulation of P-gp transporter expression and function [36-39].

Flavonoids with anticancer and chemopreventive properties abundant in traditional Chinese medicinal plants include nobiletin, tangeretin, baicalein and baicalin [40-41]. A range of compounds isolated from citrus fruits were reported to possess anticancer properties [42]. Tangeretin is a major inhibitor of P-gp efflux pump, found in orange juice. Tangeretin and another component of orange juice, nobiletin $\left(5,6,7,8,3^{\prime}, 4^{\prime}\right.$-hexamethoxyflavone), increased the steady-state uptake of vinblastine by Caco-2 cells in a concentration-dependent manner [43]. Ohtani et al. demonstrated that both citrus compounds increased the 
uptake of P-gp substrate vincristine by doxorubicin resistant human chronic myelogenous leukemia K562/ADM cells [44]. Tangeretin also inhibited P-gp and increased doxorubicin accumulation in resistant LoVo/Dx human colon adenocarcinoma cells [45]. Nobiletin strongly inhibited $\mathrm{NO}$ and $\mathrm{O}_{2}{ }^{-}$production in leukocytes, growth of human prostate carcinoma cells, TPA (12-O-tetradecanoylphorbol-13-acetate)induced skin inflammation and oxidative stress in mice [46]. Coumarin auraptene treatment led to suppression of oral carcinogenesis induced with 4-nitroquinoline 1-oxide in rats and inhibited growth in human prostate carcinoma cells [47-49]. It also suppressed TPA- and LPS (lipopolysaccharide)- induced inflammatory responses [50]. Auraptene and nobiletin were also shown to stimulate the basal ATPase activity of P-gp and improve the verapamil-stimulated ATPase activity of P-gp [51].

While many flavonoids inhibit $\mathrm{ABC}$ transporter-mediated efflux by direct interacting with the ATP- and steroid-binding sites [52], (-)epicatechin from green tea was shown to increase P-gp-mediated drug transport by heterotropic allosteric mechanism [53].

When administered with other drugs, citrus components inhibited the P-gp and CYP3A4 activity thus changing the small intestine drug absorption [54]. In addition to P-gp modulation, pharmacokinetic interaction of flavonoids with various drugs may affect the metabolism of different enzymes including CYP450s, esterases, glucuronidases, and oxidases [55-57]. Flavonoids may also modulate key targets of the apoptotic pathways. Several reports have indicated that isoflavonoids can increase the levels and activity of caspase- 3 and caspase- 9 [34, 58-61].

Tea (Camellia sinensis) consumption has been linked to reduced risk of a range of tumors such as skin, esophagus, stomach, intestine, lung, liver, pancreas, mammary gland, urinary bladder and prostate cancer [4]. (-)-Epigallocatechin gallate (EGCG), the active tea compound with cancer preventive effects, exhibited inhibitory effect on the NF- $\mathrm{kB}$ pathway in JB6 mouse epidermal cells [62] and human epidermal keratinocytes [63]. EGCG also inhibited the reporter activity of $\beta$-catenin/TCF (T cell factor) in human embryonic kidney cells HEK293 [64] as well as Wnt/B-catenin signaling in human invasive breast cancer cells [65]. EGCG and other tea catechins exert inhibitory effects on P-gp activity in human MDR epidermal carcinoma cell line KB-C2 cells [66-68].

Lignans are a group of chemical compounds found in consumable plants. They have shown antiinflammatory and antioxidant activity [69-70] as well as anticancer activity [71-73]. 
Fructus Schizandrae has been commonly used as a tonic in traditional Chinese medicine for thousands of years. The crude extract of Fructus Schizandrae (named LCC) and five schizandrins, derivatives of dibenzo[a,c]cyclooctene lignan showed multi-bioactivities such as anti-liver injury, induction of hepatic cytochrome P450, antioxidant activity, inhibition of xenobiotics metabolism and mutagenicity [74]. Schizandrin A, the active component of LCC reversed vincristine and doxorubicin resistance in human epidermal carcinoma KB cell MDR subline, human hepatocellular carcinoma Bel7402 cells and MCF-7/Dox cells. Both schizandrin A and LCC markedly increased intracellular doxorubicin accumulation, enhanced apoptosis, down-regulated P-gp protein and mRNA and total PKC expression in MDR cells. In nude mice bearing KBv200 xenograft, co-administration of LCC significantly enhanced the inhibitory effect of vincristine on tumor growth [74]. Schizandrin A restored the cytotoxic effect of doxorubicin in human promyelotic leukemia HL60/MDR cells overexpressing P-gp [75]. Another study demonstrated that schizandrin A, as a major active lignan of Wuzhi tablet (WZ; Schisandra sphenanthera extract) can inhibit P-gp-mediated efflux and CYP3A-mediated metabolism of tacrolimus [76].

The major active constituent of silymarin, silibinin, also known as silybin, is a standardized extract of the milk thistle seeds, containing a mixture of flavonolignans._Silibinin is an inhibitor of P-gp-mediated efflux, and its oxidative metabolism is catalyzed by CYP3A4. It was able to enhance oral bioavailability of paclitaxel probably due to inhibition of the P-gp transporter [77]. Silibinin also sensitized human ovarian carcinoma A2780/taxol cells to paclitaxel, increased paclitaxel-induced apoptosis and G2/M arrest due to the down-regulation of survivin and P-gp. In addition, silibinin dramatically reduced the invasive potential of A2780/taxol cells [78].

A lignan from Phyllanthus amarus, nirtetralin, was found to be the most potent in inhibiting P-gp activity as assessed by rhodamine 123 accumulation in vincristine resistant Lucena-1 cells, counterpart of leukaemia K-562 cell line. It also significantly potentiated daunorubicin-induced cell death in Lucena-1 cells. These results point to a potential role of $P$. amarus derivatives as MDR reversing agents, mainly due to their ability to synergize with the action of conventional chemotherapeutics [79].

Diarylheptanoids are phenolic compounds with heptane chain between two aromatic rings [80] abundantly found in Alnus, Zingiber, Curcuma, Alpinia, Betula and Myrica genera [81]. They are 
increasingly recognized as potential therapeutic agents with antioxidative [82], anti-inflammatory [83], antiviral [84], anticancer [85-86], hepatoprotective [87], and neuroprotective properties [88].

Curcuminoids isolated from Curcuma longa turmeric powder are mainly comprised of curcumin (curcumin I), demethoxycurcumin (curcumin II) and bisdemothoxycurcumin (curcumin III) [89]. Curcumin is one of the most studied anticancer compounds isolated from natural sources. It displays inhibitory effect on numerous $\mathrm{ABC}$ drug transporters and possesses anti-inflammatory [90], antiviral [91] and anticancer [92] actions as well as potential therapeutic effect against neurodegenerative, cardiovascular, pulmonary, metabolic, autoimmune and neoplastic diseases [93-94]. It was reported that curcumin directly inhibits Pgp, MRP1 and BCRP function and restores drug sensitivity in MDR cancer cells [95-98] and MDR tumors in mice [98]. Curcumin suppresses NF-אB activation induced by TNF, phorbol esters and hydrogen peroxide through suppression of IкB degradation [99-100]. It also inhibits the TPA-induced expression of cyclooxygenase-2 by suppressing NF- $\mathrm{KB}$ activation [101]. Curcumin also affects the $\beta$-catenin-induced cMyc expression, Wnt signaling pathway, the quantity of nuclear ß-catenin and TCF-4 proteins [102-103]. The mammalian target of rapamycin (mTOR) is a serine/threonine kinase which acts downstream of the phosphatidylinositol 3-kinase (PI3K)/Akt (protein kinase B) and regulates the cell growth and survival [104]. Curcumin has been shown to inhibit mTOR signaling pathway in cancer cells through a protein phosphatase-dependent dephosphorylation mechanism [105-106]. Curcumin also blocks P-gp function in KB-C2 cell line and displays chemosensitizing potential and chemopreventive properties [107].

Curcumin has lipophilic and water insoluble nature and it is also very rapidly metabolized. Therefore, very high doses of the drug need to be administered to reach biological efficiency. However, curcumin is well-tolerated even in higher doses and is significantly beneficial for cancer patients without reducing the activity of other drugs [108]. Curcumin treatment has also been shown to improve the outcome in patients with rheumatoid arthritis [109], chronic anterior uveitis [110], inflammatory bowel disease [111], psoriasis [112], and pancreatic cancer [113]. Multiple approaches have been proposed to improve the system delivery of curcumin, such as nanoparticles [114-115], curcumin-phospholipid complex and structural analogs [116], liposome encapsulated curcumin [117], and the curcumin-piperine combination [118]. 
Coumarins are natural plant products whose core structure is derived from the respective cinnamates via ortho-hydroxylation of the aromatic ring, trans/cis isomerization, and lactonization. These molecules exhibit various biological activities such as antibacterial, antioxidant, anti-inflammatory, rodenticidal or termiticidal [119]. Several naturally occurring and synthetic coumarins, furanocoumarin, pyranocoumarin and sesquiterpenoid coumarins are investigated for their ability to reverse MDR by inhibiting the P-gp transporter activity. To find therapeutic strategies less toxic for normal cells and more beneficial for cancer patients, the coumarin and its derivatives were used as ligands in metal complexes with platinum or palladium (II) [120]. In the breast cancer cell line with high resistance to doxorubicin (MCF-7/Dox) the effect of conferone, a coumarin of Ferula gummosa fruits, was evaluated. Among other coumarins tested in this study, only conferone enhanced doxorubicin uptake by MCF-7/Dox cells in a dose dependent manner reaching the highest potency at $10 \mu \mathrm{M}[121]$.

Praeruptorin A, a naturally existing pyranocumarin isolated from the dried root of Peucedanum praeruptorum Dunn., sensitized P-gp mediated MDR cancer cells to anticancer drugs. Its derivative, $( \pm)-3^{\prime}-$ O, 4'-O-dicinnamoyl-cis-khellactone, was even more potent in the reversal of resistance. This compound increased cellular accumulation of doxorubicin without affecting the expression level of P-gp efflux pump. ( \pm )-3'-O, 4'-O-dicinnamoyl-cis-khellactone could bind simultaneously with substrates to P-gp through an allosteric site and thus affecting transporter-substrate interactions [122-123].

A furanocoumarin, rivulobirin A, showed strong P-gp inhibition as shown by the screening of Pgp inhibitors evaluated by quinidine penetration through the Caco-2 monolayer [124]. It also increased the calcein acetoxymethyl ester (calcein-AM), a P-gp substrate, uptake into bovine brain microvascular endothelial cells (BBMEC) by the inhibition of the transporter [125]. When investigated in vivo using verapamil as a P-gp substrate the similar effect was observed. Rivulobirin A increased the ratio of verapamil concentration in the brain to plasma (B/P ratio) compared to the control, even under in vivo conditions; however, the extent of the inhibitory effect was much lower than in in vitro conditions.

From other phenolic compounds, it is significant to mention [6]-gingerol, a phenol found in ginger (Zingiber officinale). It displays inhibitory effect on the proliferation of prostate, gastric, and breast cancer cells [99]. [6]-Gingerol also inhibits the NF- $\mathrm{KB}$ activation and down-regulates $\beta$-catenin-depenent cyclin 
D1 levels inducing apoptosis in cancer cells [126-127]. Capsaicin and [6]-gingerol can also partially reverse MDR and increase the cytotoxicity of vinblastine by inhibiting the P-gp function [107].

\section{TERPENOIDS AND STEROIDS}

Terpenoids are a very diverse class of natural compounds, with common C5 isopentenoid units that comprise the main building block in more than 30,000 individual members [128-129]. Terpenoids with two isoprene units are called monoterpenes, while those containing three to six isoprene units are called sesquiterpenes, diterpenes, sesterterpenes, and triterpenes, respectively [130].

Sesquiterpenes constitute a wide family of natural compounds with substantial bioactive properties including ability to reverse MDR in cancer cells [131-132]. The activity of dihydro- $\beta$-agarofuran sesquiterpenes was investigated on mouse embryo fibroblast NIH-3T3 cells which express human P-gp, to compare the capacity of each compound for drug efflux inhibition [133]. Flow cytometry experiments showed that dihydro- $\beta$-agarofuran sesquiterpenes specifically inhibited P-gp drug transport activity in concentration-dependent manner in human abcbl-transfected NIH-3T3 cells [134]. They also prevented transport of colchicine and tetramethylrosamine and modulated transporter ATPase-activity: stimulation at low and inhibition at higher concentrations.

Diterpenes are structurally diverse class of $\mathrm{C}_{20}$ natural compounds, originating from the condensation of four isoprene units produced in mevalonate or deoxyxylulose phosphate pathways. They are commonly found in a polyoxygenated form with keto and hydroxyl groups, the latter esterified by small-sized aliphatic or aromatic acids. Thousands of diterpenes have been isolated from terrestrial and marine organisms, however a small number became clinically valuable [135]. Jatrophanes, lathyranes, euphoractine, pepluane and paraliane isolated from Euphorbia species were screened by rhodamine 123 accumulation for P-gp modulating activity in mouse lymphoma cells, human breast cancer cells MDA-MB231 (HTB-26) and MCF-7 cells. The drug accumulation in resistant cells was shown to be proportional to the hydrophobicity of diterpenes [136].

A macrocyclic lathyrane diterpene from Euphorbia lagascae, jolkinol, strongly reversed MDR phenotype in mouse lymphoma cells when compared to verapamil [137]. Jolkinol B was also highly effective in the MDR colon carcinoma cells HT-29 [138]. Among jatrophane diterpenes, euphodendroidin 
D and pepluanin A were shown to be potent inhibitors of daunomycin-efflux activity, twofold more efficient than conventional modulator cyclosporin A [139].

Phenolic diterpenes extracted from Rosmarinus officinalis possess strong antioxidative, antiinflammatory, antimicrobial and anticancer properties [140-143]. Antioxidative activity of rosemary extracts mainly originates from carnosic acid, carnosol and rosmarinic acid [140]. Rosemary derived compounds such as carnosic acid, carnosol, rosmarinic acid and ursolic acid also show substantial

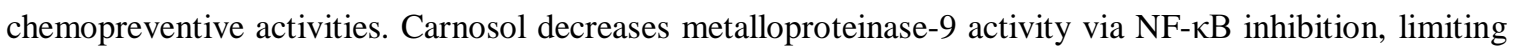
B16/F10 mouse melanoma cells invasion [143]. Carnosol also blocks the nuclear translocation of NF- $\mathrm{KB}$, phosphorylation and degradation of IкB [144] and prevents ß-catenin/APC (Adenomatous polyposis coli)associated intestinal carcinogenesis [145]. Carnosic acid and carnosol inhibit the P-gp function in human MDR KB-C2 cells chemosensitizing the cells to vinblastine [146].

Triterpenes are a chemically diverse group of natural products exhibiting a wide range of biological activities including anticancer, antibacterial, hepatoprotective, cardiovascular, antihyperlipidemic, antioxidant, anti-inflammatory, and analgesic [147].

Oleanolic acid (OA) is a triterpenic acids found in over 1,600 plants species [148]. The MDR modulating activity was tested in several oleanolic acid analogs modified at C-3, C-11, C-12 and C-28 on three human acute lymphoblastic leukemia cell lines (CCRF-CEM and the MDR sublines CCRF-VCR1000 and CCRF-ADR5000). Methyl 3,11-dioxoolean-12-en-28-olate (DIOXOL) was shown to inhibit cell growth more effectively than its precursor - oleanolic acid, and showed greater citotoxicity in the drug resistant compared to the wild-type cells [149]. Moreover, treatment with DIOXOL significantly decreased expression and inhibited the function of the P-gp efflux pump. DIOXOL acted synergistically with doxorubicin in CCRF-VCR1000 cells, demonstrating considerable MDR reversing ability [149].

Ginsenosides, abundantly found in Panax ginseng, belong to a group of saponins with triterpenoid dammarane structure or oleanolic acid structure. Ginseng has been shown to have numerous beneficial effects in cancer, diabetes mellitus, the cardiovascular system, immune system and central nervous system [102].

A study in drug-resistant KBV20C cells has demonstrated that ginsenoside Rg3, a red ginseng saponin, binds to P-gp thus blocking the efflux of drugs [150]. Additionally, $\operatorname{Rg} 3$ increased survival in mice 
implanted with doxorubicin resistant murine leukemia P388 cells. Yang et al. reported that 20(S)ginsenoside $\operatorname{Rg} 3$ improved the antitumor activity of paclitaxel in nude mice, indicating that their oral coadministration could be another valuable strategy other than the conventional i.v. method [151]. 20(S)ginsenoside $\mathrm{Rh} 2(20(S)-\mathrm{Rh} 2)$, a strong non-competitive transporter inhibitor, increased the absorption of Pgp substrates without causing longstanding P-gp expression in rats [152]. This compound also affected the MAPK/NF-кB pathway and decreased doxorubicin-induced P-gp expression in MCF-7/Adr cells, making 20(S)-Rh2 a promising candidate for MDR reversal agent development [153].

Limonoids represent a group of highly oxygenated triterpenoids found only in few plant families (Rutales, Meliaceae, and Rutaceae) [154]. They are stereochemically homogenous compounds with a 4,4,8-trimethyl-17-furanylsteroid skeleton. Limonoids and their glucosides are water soluble triterpenoid compounds that naturally occur in citrus fruit. Limonin, originally isolated from Citrus in 1841, was the first characterized compound from this group of phytochemicals [155].

Limonoids from citrus fruits have been reported to have considerable cancer chemopreventive properties. In vitro studies revealed that limonoids inhibit the growth of estrogen receptor-negative and positive human breast cancer cells and neuroblastoma cells [156]. Limonoidsobacunone, limonin, nomilin and their glucosides, and some aglycones can inhibit chemically induced carcinogenesis and show significant cytotoxicity against lung, colon, oral and skin cancer both in vitro and in vivo [157-159]. Moreover, limonoids have the ability to induce specific carcinogen-metabolizing and detoxifying enzymes, glutathione-S-transferase and quinine reductase in the liver and mucosa of the small intestine. It was reported that the activity of phase II detoxification enzyme glutathione-S-transferase in the liver of rats that consumed limonin and nomilin, increased considerably in a dose dependent manner. However, limonoidsnomilin and limonin had no significant effect on the phase I detoxification enzyme cytochrome P450 [154].

Sterols are a large group of natural secondary metabolites commonly occurring in plants and animals that possess a basic cyclopentanoperhydrophenanthrene skeleton. Plant steroids include sterols, steroid saponins, steroid alkaloids, cardiac glycosides, pregnanes, estranes and ectysteroids [130]. Cholesterol is a critical structural component of cell membranes in animals, while plant sterols are vital structural components of plant cell membranes. In addition to their activity as effective modulators of 
plasma low-density lipoprotein (LDL) cholesterols in humans [160], plant sterols also display a protective role in colon, breast and prostate cancer [161]. The main dietary phytosterols are $\beta$-sitosterol and stigmasterol, mostly consumed through edible oils, seeds, and nuts.

Anticancer activity of citrus sterols and their ability to reverse doxorubicin resistance in leukemia and human colon carcinoma was reported [162]. Because of their structural similarity to cholesterol, phytosterol glycosides can interact with the cell membrane increasing its fluidity, leading to leakage of electrolytes and metabolites and eventually cell death [163]. Unlike cholesterol, $\beta$-sitosterol is poorly absorbed from the intestine, and its concentration in the blood and tissues remains generally low. However, $\beta$-sitosterol-O-glucoside has been shown to be very effective in cell membrane proteins interaction and reversal of doxorubicin resistance [162]. It has been reported that plant sterols activate the $\alpha$ isoform of the estrogen receptor, progesterone receptor, and pregnane X receptor (PXR, NR1I2) [164]. The same group also showed that phytosterol-mediated activation of PXR leads to the expression of drug-metabolizing enzyme cytochrome P450 (CYP) CYP3A gene. Pregnane X receptor is a key regulator of human cyp3A4 and $m d r l$ genes and can be activated by a variety of drugs, xenobiotics, and bile acids [165].

Guggulsterone, a plant steroid isolated from the guggul tree (Commiphora mukul), suppresses TNF-

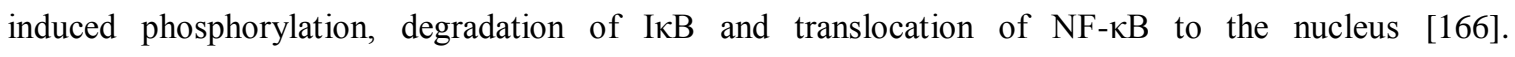
Guggulsterone also induces apoptosis in human lung carcinoma cells by inhibiting the NF- $\mathrm{kB}$ activation and anti-apoptotic gene product expression. Furthermore, guggulsterone has been shown to increase the cellular accumulation of daunorubicin in P-gp over-expressing KB-C2 cells [167].

Cannabinoids are the primary constituents of marijuana and in addition to their behavioral and psychotropic effects, they possess multiple therapeutic properties. It is widely accepted that cannabinoids produce their pharmacological effects by binding to two specific plasma membrane G protein-coupled receptors: the $\mathrm{CB} 1$ receptor, expressed mainly in the brain and in some peripheral tissues, and the $\mathrm{CB} 2$ receptor, expressed only outside the central nervous system. In recent years, numerous basic and clinical studies have confirmed that some cannabinoids exhibit the potential for therapeutic applications, including treatment of pain, nausea, vomiting, multiple sclerosis, epilepsy, cancer, anxiety, and depression [168]. Cannabinoids are also considered as natural compounds influencing P-gp activity. Cannabinol, cannabispirol and cannabidiol increased cytotoxic drug accumulation in MDR mouse lymphoma cells, 
whereas cannabidiolic acid, tetrahydrocannabidiolic acid and $\Delta^{9}$-tetrahydrocannabinol (THC) reduced it [136].

Cannabidiol, one of the four major marijuana constituents, robustly enhanced the intracellular accumulation of P-gp substrates rhodamine 123 and doxorubicin in a concentration-dependent manner in Caco-2 and LLC-PK1/MDR1 cells. It seems that it significantly inhibits P-gp-mediated drug transport, suggesting that it could potentially influence the absorption and disposition of other co-administered P-gp substrates [168]. In addition, a short-term exposure of MCF7/ABCB1 cells to cannabidiol inhibited P-gp dependent efflux of calcein, DiOC2(3) and rhodamine 123 [169].

\section{ALKALOIDS}

Alkaloids, basic nitrogenous compounds from plant sources, show a wide spectrum of biological activities including antimicrobial, antifungal, anti-inflammatory, adrenolytic, as well as cytotoxic effects against a range of human normal and cancer cell lines [170].

Alkaloids are known for their ability to inhibit P-gp. Two substructural features present in these compounds are responsible for the modulation of P-gp-associated MDR: (i) a basic nitrogen atom and (ii) two planar aromatic rings [139].

Fu et al. investigated benzylisoquinoline alkaloids as potential MDR modulators and showed that their ability to reverse MDR was linked to increased intracellular drug accumulation and inhibition of P-gp activity [171]. Isoquinoline alkaloids also increased the intracellular accumulation of P-gp substrate rhodamine 123 in a concentration-dependent manner in bovine brain capillary endothelial cells (BCEC) [172].

A study showed that emetine reversed transporter function and upregulated $m d r l$ expression in MDR cells, suggesting that emetine acts as competitive substrate for P-gp but not for MRP1 [173]. Isoquinoline alkaloids exert inhibitory effects on cell growth and induce apoptosis in a variety of cancer cells [174-176]. Isoquinoline alkaloids-mediated apoptosis in human cancer involves the activation of caspase-3 and depletion of GSH [174, 177]. Isoquinoline alkaloids were found to increase the levels of cytochrome c, Apaf-1 and the active form of caspases 3, 7, 8, and 9 in a dose-dependent manner in numerous cancer cell lines [175, 178-181]. 
Pervilleines $\mathrm{B}$ and $\mathrm{C}$ were found to restore the vinblastine sensitivity of resistant KB-V1 cells in vitro as well as of the cells implanted into $\mathrm{NCr}$ nu/nu mice. Significant inhibition was observed when vinblastine or pervilleines B and C were used in combination [182-183]. Vinblastine sensitivity of resistant KB-V1 cells was also restored by pervilleine F, a new tropane alkaloid aromatic ester obtained from a chloroform extract of the roots of Erythroxylum pervillei. In addition, it was able to partially reverse the cross-resistance of KB-V1 cells to the clinically used or experimental anticancer agents: actinomycin D, baccatin III, daunomycin, ellipticine, mithramycin A, podophyllotoxin, paclitaxel and vincristine. Cell growth was also inhibited when vinblastine and pervilleine $\mathrm{F}$ were used in combination in $\mathrm{NCr}$ nu/nu mice [184].

An interesting study of five ellipticines by Huang Y. et al, showed that two of them are P-gp substrates, whereas others appear to function as inhibitors [185]. Ellipticine and its derivatives act by multiple mechanisms involved in cell cycle arrest and initiation of apoptosis. Ellipticine was found: (i) to arrest cell cycle progression due to modulation of levels of cyclin B1 and Cdc2, and phosphorylation of Cdc2 in human mammary adenocarcinoma MCF-7 cells; (ii) to initiate apoptosis due to formation of toxic free radicals, stimulation of the Fas/Fas ligand system and modulation of proteins of Bcl-2 family in several tumor cell lines; and (iii) to induce the mitochondria-dependent apoptotic processes [186].

Capsaicin, a compound extracted from red chili peppers (Capsicum annuиm), displays chemopreventive properties and suppresses carcinogenesis in skin, colon, lung, tongue and prostate [99]. Capsaicin was reported to inhibit TNF-induced NF- $\kappa B$ activation in human myeloid ML-1a cells by

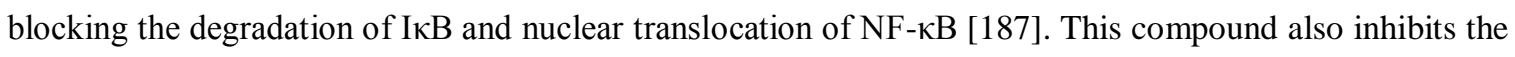
TPA -induced activation of NF- $\mathrm{KB}$ in mouse skin [188].

\section{MARINE PRODUCTS}

There are many biologically active compounds that have been isolated from marine sources, including sponge, algae, coral and ascidian [29, 189-190], that are shown to possess cytotoxic activity against tumor cells [29]. Some marine compounds, such as agosterol A, ecteinascidin 743, sipholane triterpenoids, bryostatin 1, and welwintolidones also have the ability to reverse MDR. 
Agosterol A, is a polyhydroxylated sterol acetate isolated from the marine sponge. It caused growth inhibition in colchicine treated MDR cancer cell line KB-C2, but was not toxic to the parental KB3-1 cells at the same concentration [191]. This marine compound also completely reversed the resistance to vincristine, doxorubicin, colchicine, and etoposide in KB-C2 and KB-CV60 cells [191] and inhibited P-gp and MRP1-mediated drug efflux [192].

Ecteinascidins are tetrahydroisoquinolone alkaloids isolated from the Caribbean tunicate Ecteinascidia turbinate [193]. Ecteinascidin 743 binds to the minor groove of DNA [194] and interferes with cellular transcription resulting in cell death [195]. Non-toxic concentrations of ecteinascidin 743 partially reversed the resistance to doxorubicin and vincristine in both KB-8-5 and KB-C2 MDR cells [196]. Ecteinascidin 743 was most effective in ovarian, breast, and mesenchymal tumors in phase I trials and also in refractory soft tissue sarcoma, ovarian, and breast cancer in phase II trials [197].

Triterpenoids isolated from the Red Sea sponge (Callyspongia siphonella) include four different skeletons: sipholane, siphonellane, neviotane and dahabane [198-199]. Sipholenol A directly inhibits P-gp activity and reverses MDR in cancer cells [200]. Treatment with sipholenol A increased colchicine, vinblastine and paclitaxel cytotoxicity in KB-C2 and KB-V1 cells. Sipholenone E, sipholenol L and siphonellinol D also inhibit the P-gp transporter and overcome MDR in KB-C2 cells [201], but exhibit no effect in MRP1-, MRP7- and BCRP-over-expressing cells. Sipholenol A, sipholenone E, sipholenol L and siphonellinol D strongly reversed MDR phenotype in P-gp overexpressing cancer cells, directly inhibiting the drug efflux and resulting in the accumulation of paclitaxel and calcein [202]. Previous study reported that MDR reversing ability was more prominent in sipholenone E when compared to sipholenol A [199].

Bryostatin 1 is a macrocyclic lactone isolated from the marine bryozoan (Bugula neritina). It has been shown to activate protein kinase C (PKC) [203], induce the translocation of PKC from the cytoplasm to the plasma membrane [204] and improve the P-gp activity by a PKC-mediated phosphorylation [205].

Welwitindolinones are alkaloids isolated from the blue-green algae (Hapalosiphon welwitschii), with the capacity to reverse P-gp mediated MDR [206]. N-Methylwelwitindolinone C contributed to actinomycin D and daunomycin cytotoxicity in SK-VLB-1 cell line and the cytotoxicity of paclitaxel, colchicine, vinblastine, actinomycin $\mathrm{D}$, and daunomycin in resistant breast carcinoma MCF-7/ADR cells. 


\section{OUR EXPERIENCES WITH NATURAL PRODUCTS IN COMBATING CANCER MDR}

Paclitaxel, a diterpene natural product, is one of the most active anticancer agents known [207]. Paclitaxel was originally isolated from the bark of the Pacific yew tree, Taxus brevifolia in 1971 [208]. Since a natural source of paclitaxel had a limited supply, it is now derived semi-synthetically from the inactive taxane precursor, 10-deacetylbaccatin III, found in the needles of the European yew tree, Taxus baccata [209]. Paclitaxel is currently used in clinics for the treatment of several types of tumors, including lung, breast, ovarian, head and neck cancer and advanced forms of Kaposi's sarcoma [210]. Neutropenia, neurotoxicity, cardiac effects and immuno-suppression are common side-effects of paclitaxel [211].

Paclitaxel is an anti-mitotic drug that binds to the mitotic spindle microtubules and prevents their depolimerization, impeding normal progress of cell division [212]. Target molecule for paclitaxel is $\beta$ tubulin subunit in polymerized microtubules. Paclitaxel achieves its cytotoxic effect by suppresing dynamics of mitotic spindle, which induces cell cycle arrest in G2/M phase and eventually cell death by apoptosis [213]. Paclitaxel also affects the process of tumor-angiogenesis through inhibition of matrix metaloproteinases production [214] and vascular endothelial growth factor (VEGF) secretion [215].

Despite the success of paclitaxel in the clinic, development of MDR limits its effectiveness in cancer treatment, specially the overexpression of drug efflux transporter P-gp [216]. Paclitaxel resistance can also develop from $\beta$-tubulin gene mutations, changes in $\beta$-tubulin isoforms expression and increased microtubule dynamics associated with altered microtubule-associated protein expression [207]. Moreover, the disturbance of the normal functioning of some signaling pathways such as cell cycle control, cell growth and apoptosis can have an important role in the development of resistance to paclitaxel [217].

It was shown that continuous paclitaxel treatment induces acquisition of MDR phenotype in human colorectal carcinoma and glioblastoma cell lines [218]. Namely, after continuous exposure to paclitaxel, both cell lines overexpressed P-gp and developed cross-resistance to different anticancer agents. Our study revealed that paclitaxel treatment induced extensive cell death in colorectal cancer cells that were accumulated in subG0 phase of the cell cycle, while glioblastoma cells died during interphase (G1, S or G2). Although continuous application of paclitaxel caused the acquisition of MDR, the levels of mrpl mRNA that codes for another membrane transporter was decreased in both cell lines. Furthermore, 
significant depletion of $g s t-\pi$ gene expression and glutathione concentration, a component of glutathione detoxification system, was observed in glioblastoma cell line after continuous paclitaxel treatment. Additionally, the secretion of VEGF was inhibited by single paclitaxel treatment of colorectal cancer and in continuous treatment of glioblastoma cell lines [218].

This implies that development of MDR phenotype by exposure to paclitaxel accounts for some properties, which are favorable for the action of other chemotherapeutics. Lower antioxidative capacity of paclitaxel resistant cells may contribute to the better effect of prooxidative compounds, which are not substrates for P-gp.

Jatrophane diterpenes. Euphorbia species (Euphorbiaceae) have been described in the medical literature of antique Greeks and Romans as plants that cure cancer [219]. Plants of the Euphorbia species, which are considered as one of the most common elements of Mediterranean landscape, contain unique profile of bioactive plant metabolites, belonging to diterpene polyesters (e.g., ingenane, lathyrane, tigliane, jatrophane, and daphnane). These compounds showed interesting pharmacological activities, such as antiproliferative, cytotoxic, antiviral, antibacterial, platelet aggregation-inhibiting, and vasoconstrictor activities [220]. Recent studies have recognized jatrophane diterpenes as potent and specific inhibitors of Pgp [221]. Many powerful inhibitors have been identified among jatrophane diterpenes and some of them have higher potencies for inhibiting P-gp than conventional P-gp modulators cyclosporin A and verapamil [220]. The cytotoxic activities of jatrophane diterpenes have also been studied previously on different cancer cell lines [222-223]. Jatrophane diterpens stimulate purified tubulin assembly in vitro in the same way as paclitaxel, but without inducing cell cycle arrest in the G2/M phase [224].

Based on an unique bicyclo [10.3.0]-pentadecane skeleton, structural diversity of jatrophanes originates only from differences in the substitution pattern [225]. Isolation of high numbers of natural structurally-related analogs has constituted these compounds as ideal target for the study of the Structure Activity Relationship (SAR), without any chemical modification [226]. The interesting biological properties and the unusual molecular architecture of jatrophane diterpenes from Euphorbia species have attracted considerable interest in research on this type of compounds. 
Euphorbia dendroides $L$. is a tree-like semi-succulent spurge growing on rocky coastal places in the Western Mediterranean area [226]. As part of an investigation of spurges from the southeastern Balkan region, jatrophane diterpenoid fraction was purified from Euphorbia dendroides. Six new jatrophanes (euphodendrophanes A-F) and a new tigliane (euphodendriane A) were isolated and their structures elucidated by spectroscopic techniques [227]. These compounds showed moderate inhibitory effect on the in vitro growth of four human cancer cell lines: non-small cell lung carcinoma (NCI-H460) and its resistant counterpart (NCI-H460/R), colorectal carcinoma (DLD1), and glioblastoma (U87). The most effective in inhibiting cancer cell growth were jatrophane euphodendrophane $\mathrm{B}$ and tigliane euphodendriane A. The MDR phenotype in NCI-H460/R cells did not significantly change the inhibitory pattern of tested compounds compared to their sensitive counterparts [227]. The most effective jatrophanetype compound (euphodendrophane B) and its structurally closely related derivative (euphodendrophane A) were non-toxic for normal cells (peripheral blood mononuclear cells), showing selectivity towards cancer cells [228]. Treatment with euphodendrophane A/B increased accumulation of P-gp supstrate rhodamine 123 in resistant NCI-H460/R cells more than standard P-gp inhibitor dex-verapamil. Both jatrophanes significantly reduced the level of $m d r l$ gene expression that codes for P-gp in sensitive NCI-H460 cells, suggesting that they could not induce the development of resistance [228]. Simultaneous treatment of euphodendrophane $\mathrm{A} / \mathrm{B}$ with paclitaxel or doxorubicin induced strong synergistic effect in resistant $\mathrm{NCI}$ H460/R cells. Furthermore, these jatrophanes behaved as potent MDR modulators by reversing resistance to paclitaxel and doxorubicin [228]. However, synergistic effect of jatrophanes in combination with classic chemotherapeutics is not caused merely by $\mathrm{P}$-gp inhibition. In combination with paclitaxel, both jatrophanes induced cell killing and changed cell cycle distribution leading to G2/M arrest. Disturbance of cell cycle after combined treatment of jatrophanes with paclitaxel was partially due to their mutual effect on microtubule assembly since euphodendrophane A stimulated purified tubulin assembly in vitro in the same manner as paclitaxel [228]. Euphodendrophane A/B also exerted an anti-angiogenic effect by decreasing the vascular endothelial growth factor (VEGF) secretion [228].

In addition, 13 new jatrophane diterpenoids (euphodendrophane G-P, Q-S) were isolated from the latex of Euphorbia dendroides [229]. In this study, new jatrophane diterpenoids were tested for their P-gp inhibiting activity on three different human MDR cancer cell lines. Among the investigated 
jatrophanes, euphodendrophane $\mathrm{H}$ and $\mathrm{K}$ were found to be the most powerful inhibitors of P-gp in MDR non-small cell lung carcinoma cell line NCI-H460/R [229] (Fig. 3). Their efficacy was significantly higher than standard P-gp inhibitor dex-verapamil. The highest increase in the accumulation of rhodamine 123 and complete blockade of P-gp pump were observed in colorectal MDR cancer cells (DLD1-TxR) treated with euphodendrophane H and K [229]. Additionally, euphodendrophane H significantly sensitized NCI-H460/R and DLD1-TxR cells to paclitaxel, similar to well-known P-gp inhibitors dex-verapamil and tariqudar [230]. Moreover, the lower concentration of paclitaxel exerted anti-mitotic effect by leading to cell cycle arrest at G2/M phase in combination with euphodendrophane H in NCI-H460/R cells [230].

\section{Euphodendrophane H}
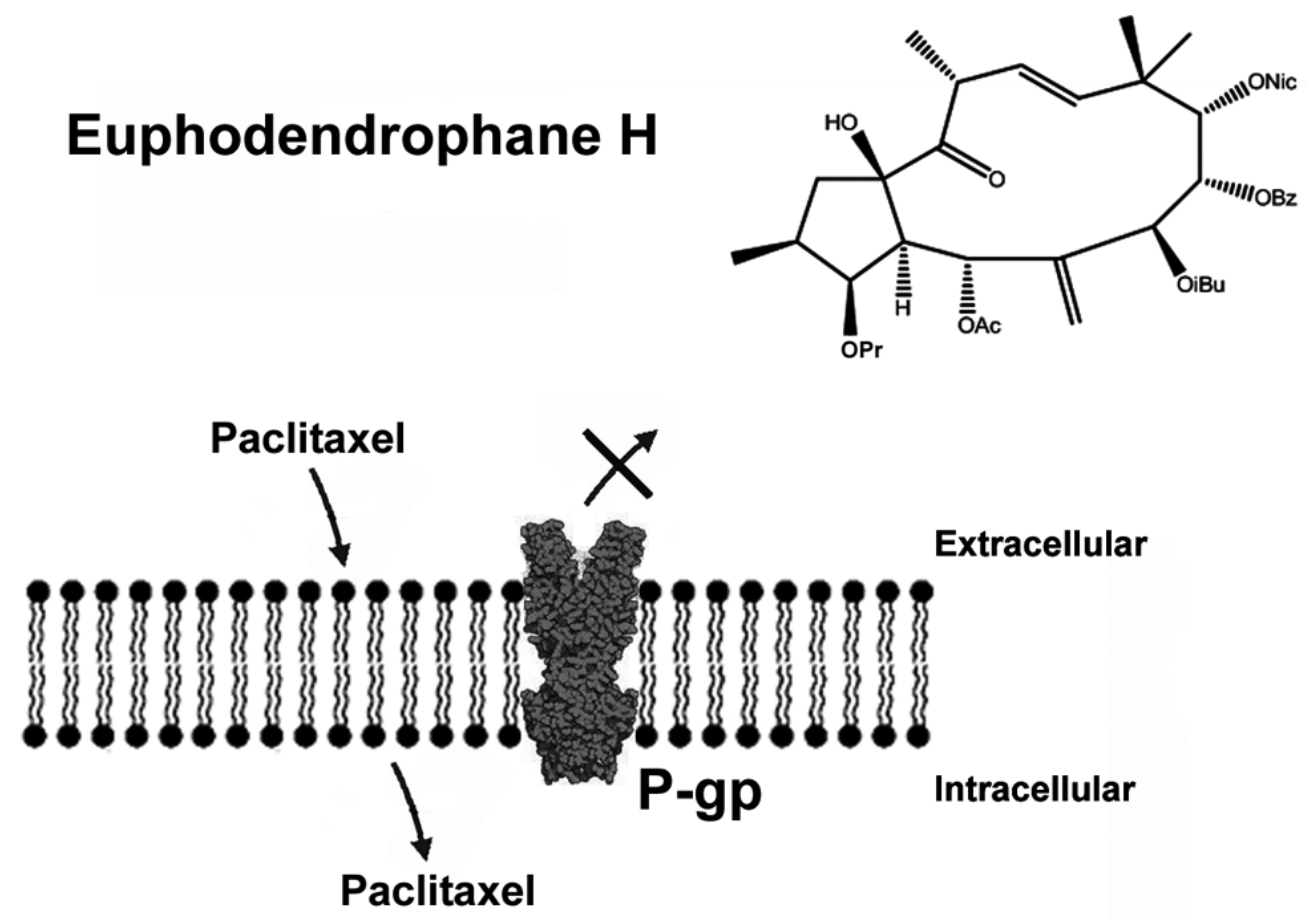

Fig. (3). Euphodendrophane $\mathrm{H}$ is a potent inhibitor of the P-gp transporter in MDR cancer cells. This natural compound increases the intracellular accumulation of the P-gp substrates such as paclitaxel thus sensitizing MDR cancer cells.

Diarylheptanoids, naturally occurring phenolic compounds, can be found in acyclic and cyclic forms, of which the latter occur less frequently. Our extended study of diarylheptanoids from the bark of black alder (Alnus glutinosa) has resulted in the isolation of 20 diarylheptanoids, ten of which have 
not previously been reported [231]. Of the isolated compounds, platyphylloside, platyphyllonol-5-O- $\beta-\mathrm{D}^{-}$ xylopyranoside, alnuside B, hirsutenone as well as two new diarylheptanoids with a p-coumaroyl group exerted the most potent cytotoxic effect against non-small cell lung carcinoma cells NCI-H460 and their MDR counterparts NCI-H460/R. These compounds exhibited considerably higher anticancer activity compared to diarylheptanoid curcumin, which served as a positive control [231]. Compounds alnuside, B, hirsutenone and two new diarylheptanoids with a p-coumaroyl group displayed significant selectivity towards the cancer cells since they were non-toxic for normal human keratinocytes (HaCaT) [231]. Additionally, the effects of the most tested diarylheptanoids did not depend on the presence of the MDR phenotype. Furthermore, only diarylheptanoids alnuside A and methylhirsutanonol suppressed P-gp function. Their ability to increase the accumulation of the P-gp substrate doxorubicin was comparable with that of curcumin [231].

One of the most potent diarylheptanoids platyphylloside and its newly discovered analog with p-coumaroyl group was further studied to evaluate their antioxidant and cytoprotective activity in nonsmall cell lung carcinoma cells NCI-H460 and normal human keratinocytes HaCaT [232]. Both diarylheptanoids induced apoptosis in NCI-H460 cells (Fig. 4). However, they failed to improve the doxorubicin effect on cell death in these cancer cells [232]. Moreover, both diarylheptanoids diminished the effect of doxorubicin on apoptosis in HaCaT cells [232-233]. The autophagy induced by new analog of platyphylloside might be responsible for the reduced apoptosis observed in $\mathrm{HaCaT}$ cells exposed to doxorubicin [233]. Tested diarylheptanoids antagonized the effects of either doxorubicin or cisplatin significantly increasing their $\mathrm{IC}_{50}$ values [232-233]. Although present in cancer cells, the observed antagonism was more pronounced in normal cells [232]. Platyphylloside induced the retention of doxorubicin in cytoplasm and reduced mitochondrial fragmentation associated with doxorubicin application [232]. New analog of platyphylloside reduced the reactive oxygen species (ROS) production induced by cisplatin [232]. Both compounds increased the mRNA expression of enzymes involved in ROS elimination (Mn-SOD and HIF-1 $\alpha$ ) [232]. Both diarylheptanoids protected HaCaT cells against doxorubicin-induced DNA damage [233]. They also significantly promoted migration and affected F-actin distribution [233]. 


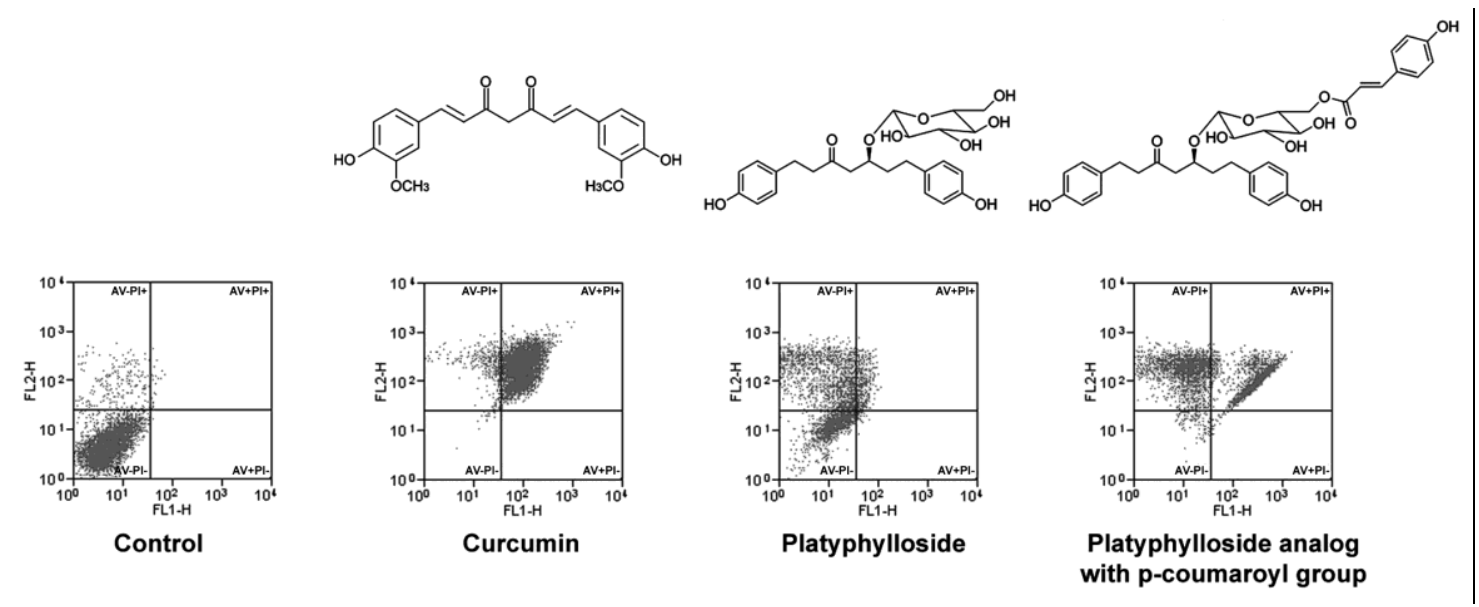

Fig. (4). Diarylheptanoids platyphylloside and its recently identified analog with p-coumaroyl group induce cell death in non-small cell lung carcinoma cells NCI-H460 after $72 \mathrm{~h}$ treatment. Unlike curcumin, platyphylloside and its analog with p-coumaroyl group lead cancer cells into necrotic cell death. The samples were analyzed for green fluorescence (Annexin-V-FITC, FL1-H) and red fluorescence (Propidium Iodide, FL2-H) by flow-cytometry. The assay distinguishes viable cells (AV-PI-), apoptotic cells (AV+PI-), late apoptotic and necrotic cells (AV+PI+) and secondary necrotic or dead cells (AV-PI+).

Protoflavones have recently emerged as a class of natural compounds with prospective anticancer potential [234]. These unique flavonoids express an unusual non-aromatic B-ring; this typically p-quinol moiety makes them much stronger prooxidants than typical flavones. As such, these compounds can severely interfere with the redox homeostasis of cancer cells on multiple levels, leading to an oxidative stress-mediated apoptosis [235].

Desmosdumotin B, an analog of a flavonoid containing a non-aromatic A-ring, showed great promise against P-gp overexpressing MDR cell lines [236]. Moreover, several phenolic compounds, including xanthones and flavonoids have been reported to exert selective cytotoxicity against MRP1 overexpressing cancer cells typically due to their intrinsic prooxidant properties accompanied with an ability to promote glutathione (GSH) efflux through this ABC transporter [237].

MDR-selective anticancer activity of six protoflavones was investigated in four MDR/non-MDR cancer cell line pairs: three pairs of human cancer and a pair of rat glioma cell lines [238]. Protoflavones showed significant cytotoxicity against all cancer cell lines and selectivity toward MDR cancer cells 
adapted to classic cytostatics. Interestingly, inverse sensitivity vs. MDR selectivity pattern was observed meaning that the less active compounds were more selective against MDR cancer cells. Compounds 6methylprotoflavone and new protoflavone derivative 6-bromoprotoflavone induced a decrease in G1 phase followed by arrest in G2/M phase of cell cycle in MDR cells. The levels of reactive oxygen and nitrogen species (ROS/RNS) between MDR and non-MDR cells significantly differed upon exposure to 6bromoprotoflavone, accompanied with changes in the glutathione (GSH) levels and in the expression of manganese superoxide dismutase (MnSOD), glutathione-S-transferase $\pi$ (GST $\pi$ ) and hypoxia inducible factor-1 $\alpha(\mathrm{HIF}-1 \alpha)[238]$.

Antimicrobial peptides (AMPs) are innate immunity peptides, which normally provide a first line of defense against invading microbes on epithelial tissues [239]. Interaction of AMPs with target cell membranes eventually leads to the disturbance or destruction of membrane potential and its barrier function [240]. Most AMPs specifically target bacteria and are almost non-toxic for host cells [241]. This differential sensitivity is driven by electrostatic interactions between cationic AMPs and the negatively charged lipids of the bacterial membranes [242]. The human cell plasma membrane surface consists of the zwitterionic choline phospholipids and sphingomyelin and almost lacks anionic phospholipids, while the bacterial cytoplasmic membrane is characterized by a significant amount of negatively charged phospholipids, mainly phosphatidylglycerol [243]. Negatively charged phosphatidylserine (PS), a constituent of the inner layer of human cytoplasmic membranes, can be translocated to the outer leaflet during the loss of membrane asymmetry [244]. Surface exposed PS then serves as a marker for the clearance of pathological or aged erythrocytes and apoptotic cells from the bloodstream by monocytes and macrophages [245].

It has been shown that various cancer cells have elevated surface levels of negatively charged phospholipids, i.e., PS [246-247]. It has been suggested that surface-exposed PS makes these cells susceptible to the cationic, membranolytic peptides [247]. There are evidences that P-gp also transports endogenous PS [248]. The increase of negatively charged PS on the surface of MDR cancer cells, due to Pgp activity, could make these cells more vulnerable to AMPs than other cancer cells that possess less P-gp molecules. 
Therefore, the effects of cationic peptide NK-2, which is an internal fragment of porcine NK-lysin, were examined for the potency to discriminate and preferentially eliminate P-gp overexpressing cancer cells (Fig. 5). To that end, MDR non-small cell lung carcinoma (NCI-H460/R) and colorectal carcinoma (DLD1-TxR) cell lines with high P-gp expression were used [249]. NK-2 inhibited the growth of MDR cancer cells and their sensitive counterparts. Importantly, the NK-2 effect was selective regarding cancer cells, since human normal keratinocytes were not affected by NK-2. NK-2 preferentially bound to P-gp high-expressing cancer cells since it was able to distinguish them from cancer cells expressing low levels of or even no P-gp. Acting in 'carpet-like' manner NK-2 co-localized with P-gp on the MDR cancer cell membrane. Furthermore, the inhibition of P-gp reduced the effect of NK-2 on MDR cancer cell lines and, vice versa, NK-2 decreased P-gp mediated transport. Importantly, MDR cancer cells that survived NK-2 treatment had decreased P-gp expression and were more susceptible to doxorubicin [249]. These results recognized NK-2 as an MDR-selective agent able to exploit the presence of P-gp and preferentially eliminate such cells. 

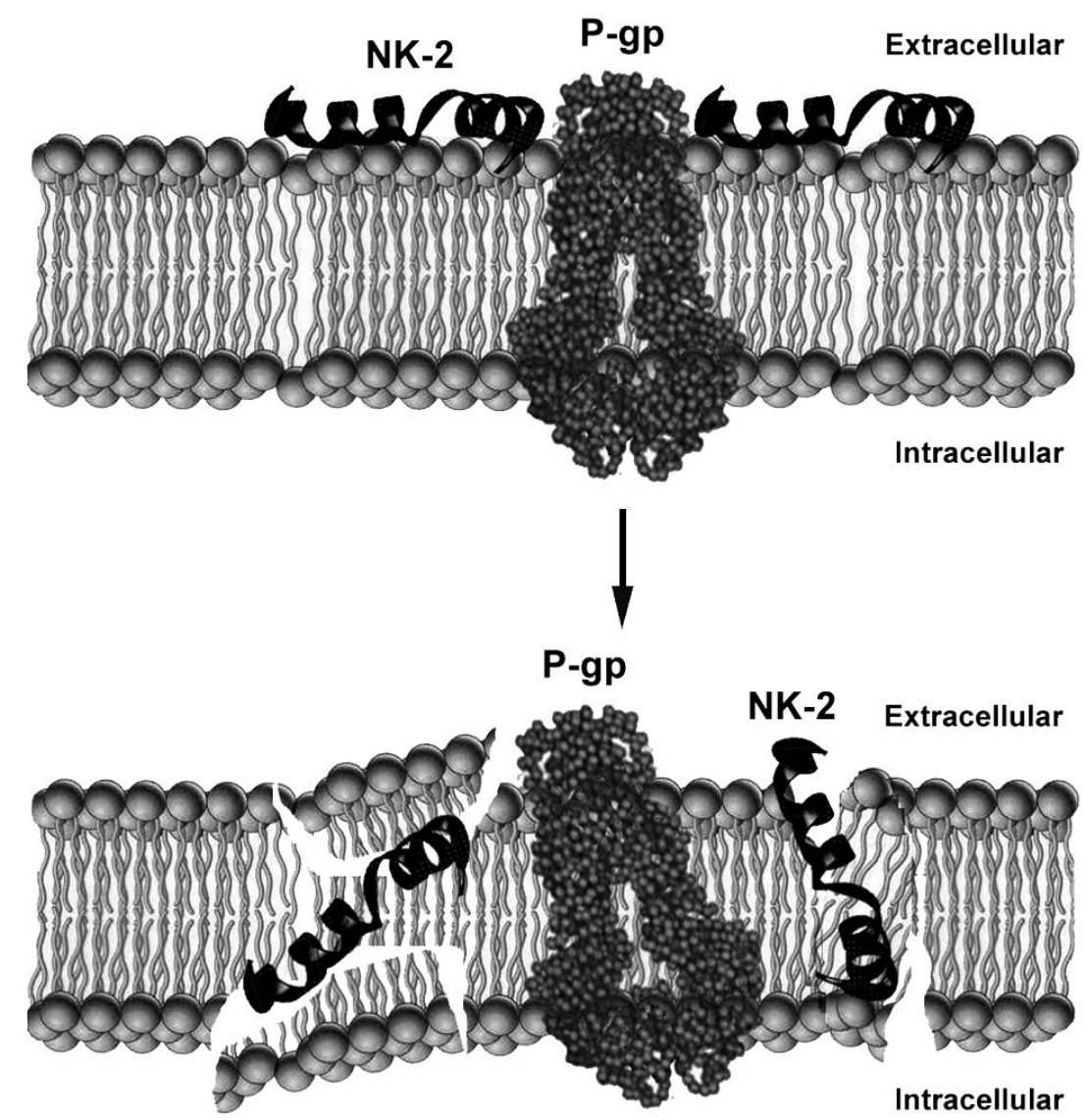

Fig. (5). Cationic peptide NK-2, an internal fragment of porcine NK-lysin, discriminates P-gp overexpressing cancer cells from other cells expressing low levels or no P-gp due to the higher presence of negatively charged phosphatidylserine on the outer leaflet of cell membrane. In a 'carpet-like' manner NK2 co-localizes with P-gp on the plasma membrane and lyses the membrane of MDR cancer cells. 


\section{CONCLUSION}

Development of MDR is a severe limitation for successful cancer chemotherapy. Many natural products interact with MDR cancer cells, some as substrates for efflux pumps and other as their inhibitors. Continuous discovery of new MDR inhibitors from natural sources significantly contributes to the development of new approaches for overcoming MDR.

Several studies were conducted to identify natural compounds that could directly inhibit P-gp, suppress its expression or selectively kill P-gp over-expressing cells. With these approaches, we tried to understand better the mechanisms of MDR and the modalities to circumvent this problem. Cancer cell lines developed after continuous exposure to doxorubicin or paclitaxel that are also natural products, were employed as MDR models. Although considerable differences exist among used MDR models, they share similar resistant phenotype due to elevated P-gp expression in all of them. It was shown that euphodendrophanes, diarylheptanoides and protoflavones possess new qualities as anticancer agents in the context of MDR. Considering the wide distribution and availability of their source plants, these compounds are valuable for new cancer treatment and prevention approaches.

In addition, anticancer peptide NK-2, originated from an animal source - porcine, discriminates P-gp highexpressing cancer cells and eliminates them from cancer cell population.

Considering that interest in natural products and their derivatives recently stagnated, this review along with the efforts of other investigators aims to recover the influence of natural products research in cancer, particularly in finding new strategies for fighting chemoresistance in cancer.

\section{CONFLICT OF INTEREST}

The authors declare that this article content has no conflicts of interest.

\section{ACKNOWLEDGMENTS}

The authors acknowledge the support from the Ministry of Education, Science and Technological Development of the Republic of Serbia (Grant No III41031) and COST Actions CM1106 (Chemical 
Approaches to Targeting Drug Resistance in Cancer Stem Cells) and CM1407 (Challenging organic syntheses inspired by nature - from natural products chemistry to drug discovery).

\section{REFERENCES}

[1] Roepe PD, Wei LY, Cruz J, Carlson D. Lower electrical membrane potential and altered pHi homeostasis in multidrug-resistant (MDR) cells: further characterization of a series of MDR cell lines expressing different levels of P-glycoprotein. Biochemistry, 1993; 32: 11042-56.

[2] Gros P, Croop J, Housman D. Mammalian multidrug resistance gene: complete cDNA sequence indicates strong homology to bacterial transport proteins. Cell, 1986; 47: 371-80.

[3] Faber KN, Muller M, Jansen PL. Drug transport proteins in the liver. Adv Drug Deliv Rev, 2003; 55: 107-24.

[4] Szakacs G, Paterson JK, Ludwig JA, Booth-Genthe C, Gottesman MM. Targeting multidrug resistance in cancer. Nat Rev Drug Discov, 2006; 5: 219-34.

[5] Shukla S, Wu CP, Ambudkar SV. Development of inhibitors of ATP-binding cassette drug transporters: present status and challenges. Expert Opin Drug Metab Toxicol, 2008; 4: 205-23.

[6] Szakacs G, Varadi A, Ozvegy-Laczka C, Sarkadi B. The role of ABC transporters in drug absorption, distribution, metabolism, excretion and toxicity (ADME-Tox). Drug Discov Today, 2008; 13: 379-93.

[7] Penson RT, Oliva E, Skates SJ, Glyptis T, Fuller AF, Jr., Goodman A, Seiden MV. Expression of multidrug resistance-1 protein inversely correlates with paclitaxel response and survival in ovarian cancer patients: a study in serial samples. Gynecol Oncol, 2004; 93: 98-106.

[8] Steinbach D, Sell W, Voigt A, Hermann J, Zintl F, Sauerbrey A. BCRP gene expression is associated with a poor response to remission induction therapy in childhood acute myeloid leukemia. Leukemia, 2002; 16: 1443-7.

[9] van den Heuvel-Eibrink MM, Wiemer EA, Prins A, Meijerink JP, Vossebeld PJ, van der Holt B, Pieters R, Sonneveld P. Increased expression of the breast cancer resistance protein (BCRP) in relapsed or refractory acute myeloid leukemia (AML). Leukemia, 2002; 16: 833-9.

[10] Yang K, Wu J, Li X. Recent advances in the research of P-glycoprotein inhibitors. Biosci Trends, 2008; 2: 137-46.

[11] Aoki S, Yoshioka Y, Miyamoto Y, Higuchi K, Setiawan A, Murakami N, Chen ZS, Sumizawa T, Akiyama S, Kobayashi M. Agosterol A, a novel polyhydroxylated sterol acetate reversing multidrug resistance from a marine sponge of Spongia sp. Tetrahedron Lett, 1998: 6303-6306.

[12] Nobili S, Landini I, Mazzei T, Mini E. Overcoming tumor multidrug resistance using drugs able to evade P-glycoprotein or to exploit its expression. Med Res Rev, 2012; 32: 1220-62.

[13] Cortes J, Baselga J. Targeting the microtubules in breast cancer beyond taxanes: the epothilones. Oncologist, 2007; 12: 271-80.

[14] Cordell GA. Natural Products in Drug Discovery - Creating a New Vision. Phytochem Rev, 2002: 261- 273.

[15] Nobili S, Lippi D, Witort E, Donnini M, Bausi L, Mini E, Capaccioli S. Natural compounds for cancer treatment and prevention. Pharmacol Res, 2009; 59: 365-78.

[16] Newman DJ, Cragg GM. Natural products as sources of new drugs over the last 25 years. J Nat Prod, 2007; 70: 461-77.

[17] Eid SY, El-Readi MZ, Fatani SH, Eldin EEMN, Wink M. Natural Products Modulate the Multifactorial Multidrug Resistance of Cancer Pharmacology \& Pharmacy 2015: 46-176

[18] Rabindran SK, Ross DD, Doyle LA, Yang W, Greenberger LM. Fumitremorgin C reverses multidrug resistance in cells transfected with the breast cancer resistance protein. Cancer Res, 2000; 60: 47-50. 
[19] Allen JD, van Loevezijn A, Lakhai JM, van der Valk M, van Tellingen O, Reid G, Schellens JH, Koomen GJ, Schinkel AH. Potent and specific inhibition of the breast cancer resistance protein multidrug transporter in vitro and in mouse intestine by a novel analogue of fumitremorgin C. Mol Cancer Ther, 2002; 1: 417-25.

[20] Mann J. Natural Products: Their Chemistry and Biological Significance. Longman Scientific \& Technical, Wiley: Harlow, Essex, England 1994.

[21] Wang HK, Xia Y, Yang ZY, Natschke SL, Lee KH. Recent advances in the discovery and development of flavonoids and their analogues as antitumor and anti-HIV agents. Adv Exp Med Biol, 1998; 439: 191-225.

[22] Choi SU, Ryu SY, Yoon SK, Jung NP, Park SH, Kim KH, Choi EJ, Lee CO. Effects of flavonoids on the growth and cell cycle of cancer cells. Anticancer Res, 1999; 19: 5229-33.

[23] Selway JW. Antiviral activity of flavones and flavans. Prog Clin Biol Res, 1986; 213: 521-36.

[24] Cushman M, Zhu H, Geahlen RL, Kraker AJ. Synthesis and biochemical evaluation of a series of aminoflavones as potential inhibitors of protein-tyrosine kinases p56lck, EGFr, and p60v-src. J Med Chem, 1994; 37: 3353-62.

[25] Cotelle N, Bernier JL, Henichart JP, Catteau JP, Gaydou E, Wallet JC. Scavenger and antioxidant properties of ten synthetic flavones. Free Radic Biol Med, 1992; 13: 211-9.

[26] Crozier A, Clifford MN, Ashihara H. Plant Secondary Metabolites: Occurrence, Structure and Role in the Human Diet. Blackwell Pub: Oxford, Ames, Iowa 2006.

[27] Leslie EM, Mao Q, Oleschuk CJ, Deeley RG, Cole SP. Modulation of multidrug resistance protein 1 (MRP1/ABCC1) transport and atpase activities by interaction with dietary flavonoids. Mol Pharmacol, 2001; 59: 1171-80.

[28] Wu CP, Calcagno AM, Hladky SB, Ambudkar SV, Barrand MA. Modulatory effects of plant phenols on human multidrug-resistance proteins 1, 4 and 5 (ABCC1, 4 and 5). FEBS J, 2005; 272: 4725-40.

[29] Haefner B. Drugs from the deep: marine natural products as drug candidates. Drug Discov Today, 2003; 8: 536-44.

[30] Hertog MG, Hollman PC, Katan MB, Kromhout D. Intake of potentially anticarcinogenic flavonoids and their determinants in adults in The Netherlands. Nutr Cancer, 1993; 20: 21-9.

[31] Somerset SM, Johannot L. Dietary flavonoid sources in Australian adults. Nutr Cancer, 2008; 60: 442-9.

[32] Bast A, Haenen GR, Bruynzeel AM, Van der Vijgh WJ. Protection by flavonoids against anthracycline cardiotoxicity: from chemistry to clinical trials. Cardiovasc Toxicol, 2007; 7: 154-9.

[33] Le Good JA, Ziegler WH, Parekh DB, Alessi DR, Cohen P, Parker PJ. Protein kinase C isotypes controlled by phosphoinositide 3-kinase through the protein kinase PDK1. Science, 1998; 281: 2042-5.

[34] Nguyen TT, Tran E, Nguyen TH, Do PT, Huynh TH, Huynh H. The role of activated MEK-ERK pathway in quercetin-induced growth inhibition and apoptosis in A549 lung cancer cells. Carcinogenesis, 2004; 25: 647-59.

[35] Mojsin M, Vicentic JM, Schwirtlich M, Topalovic V, Stevanovic M. Quercetin reduces pluripotency, migration and adhesion of human teratocarcinoma cell line NT2/D1 by inhibiting Wnt/beta-catenin signaling. Food Funct, 2014; 5: 2564-73.

[36] Di Pietro A, Conseil G, Perez-Victoria JM, Dayan G, Baubichon-Cortay H, Trompier D, Steinfels E, Jault JM, de Wet H, Maitrejean M, Comte G, Boumendjel A, Mariotte AM, Dumontet C, McIntosh DB, Goffeau A, Castanys S, Gamarro F, Barron D. Modulation by flavonoids of cell multidrug resistance mediated by P-glycoprotein and related ABC transporters. Cell Mol Life Sci, 2002; 59: 307-22.

[37] Kioka N, Hosokawa N, Komano T, Hirayoshi K, Nagata K, Ueda K. Quercetin, a bioflavonoid, inhibits the increase of human multidrug resistance gene (MDR1) expression caused by arsenite. FEBS Lett, 1992; 301: 307-9.

[38] Bansal T, Awasthi A, Jaggi M, Khar RK, Talegaonkar S. Pre-clinical evidence for altered absorption and biliary excretion of irinotecan (CPT-11) in combination with quercetin: possible contribution of P-glycoprotein. Life Sci, 2008; 83: 250-9.

[39] Borska S, Sopel M, Chmielewska M, Zabel M, Dziegiel P. Quercetin as a potential modulator of P-glycoprotein expression and function in cells of human pancreatic carcinoma line resistant to daunorubicin. Molecules, 2010; 15: 857-70. 
[40] Mencherini T, Campone L, Piccinelli AL, Mesa MG, Sanchez DM, Aquino RP, Rastrelli L. HPLC-PDA-MS and NMR characterization of a hydroalcoholic extract of Citrus aurantium L. var. amara peel with antiedematogenic activity. J Agric Food Chem, 2013; 61: 1686-93.

[41] Yu MW, Lou SN, Chiu EM, Ho CT. Antioxidant activity and effective compounds of immature calamondin peel. Food Chem, 2013; 136: 1130-5.

[42] Ju-Ichi M. [Chemical study of citrus plants in the search for cancer chemopreventive agents]. Yakugaku Zasshi, 2005; 125: 231-54.

[43] Takanaga H, Ohnishi A, Yamada S, Matsuo H, Morimoto S, Shoyama Y, Ohtani H, Sawada Y. Polymethoxylated flavones in orange juice are inhibitors of P-glycoprotein but not cytochrome P450 3A4. J Pharmacol Exp Ther, 2000; 293: 230-6.

[44] Ohtani H, Ikegawa T, Honda Y, Kohyama N, Morimoto S, Shoyama Y, Juichi M, Naito M, Tsuruo T, Sawada Y. Effects of various methoxyflavones on vincristine uptake and multidrug resistance to vincristine in P-gp-overexpressing K562/ADM cells. Pharm Res, 2007; 24: 1936-43.

[45] Wesolowska O, Wisniewski J, Sroda-Pomianek K, Bielawska-Pohl A, Paprocka M, Dus D, Duarte $\mathrm{N}$, Ferreira MJ, Michalak K. Multidrug resistance reversal and apoptosis induction in human colon cancer cells by some flavonoids present in citrus plants. J Nat Prod, 2012; 75: 1896-902.

[46] Murakami A, Nakamura Y, Torikai K, Tanaka T, Koshiba T, Koshimizu K, Kuwahara S, Takahashi Y, Ogawa K, Yano M, Tokuda H, Nishino H, Mimaki Y, Sashida Y, Kitanaka S, Ohigashi H. Inhibitory effect of citrus nobiletin on phorbol ester-induced skin inflammation, oxidative stress, and tumor promotion in mice. Cancer Res, 2000; 60: 5059-66.

[47] Tanaka T, Kawabata K, Kakumoto M, Makita H, Hara A, Mori H, Satoh K, Murakami A, Kuki W, Takahashi Y, Yonei H, Koshimizu K, Ohigashi H. Citrus auraptene inhibits chemically induced colonic aberrant crypt foci in male F344 rats. Carcinogenesis, 1997; 18: 2155-61.

[48] Tanaka T, Kawabata K, Kakumoto M, Matsunaga K, Mori H, Murakami A, Kuki W, Takahashi Y, Yonei H, Satoh K, Hara A, Maeda M, Ota T, Odashima S, Koshimizu K, Ohigashi H. Chemoprevention of 4-nitroquinoline 1-oxide-induced oral carcinogenesis by citrus auraptene in rats. Carcinogenesis, 1998; 19: 425-31.

[49] Tang M, Ogawa K, Asamoto M, Hokaiwado N, Seeni A, Suzuki S, Takahashi S, Tanaka T, Ichikawa K, Shirai T. Protective effects of citrus nobiletin and auraptene in transgenic rats developing adenocarcinoma of the prostate (TRAP) and human prostate carcinoma cells. Cancer Sci, 2007; 98: 471-7.

[50] Murakami A, Nakamura Y, Tanaka T, Kawabata K, Takahashi D, Koshimizu K, Ohigashi H. Suppression by citrus auraptene of phorbol ester-and endotoxin-induced inflammatory responses: role of attenuation of leukocyte activation. Carcinogenesis, 2000; 21: 1843-50.

[51] Nabekura T, Yamaki T, Kitagawa S. Effects of chemopreventive citrus phytochemicals on human P-glycoprotein and multidrug resistance protein 1. Eur J Pharmacol, 2008; 600: 45-9.

[52] Conseil G, Baubichon-Cortay H, Dayan G, Jault JM, Barron D, Di Pietro A. Flavonoids: a class of modulators with bifunctional interactions at vicinal ATP- and steroid-binding sites on mouse Pglycoprotein. Proc Natl Acad Sci U S A, 1998; 95: 9831-6.

[53] Johnson WW, Wang EJ, Barecki-Roach M. Allosteric Elevation of P-Glycoprotein Function by a Catechin in Green Tea. Drug Metab Rev, 2002: 87.

[54] Dahan A, Altman H. Food-drug interaction: grapefruit juice augments drug bioavailability-mechanism, extent and relevance. Eur J Clin Nutr, 2004; 58: 1-9.

[55] Dresser GK, Bailey DG. The effects of fruit juices on drug disposition: a new model for drug interactions. Eur J Clin Invest, 2003; 33 Suppl 2: 10-6.

[56] Evans AM. Influence of dietary components on the gastrointestinal metabolism and transport of drugs. Ther Drug Monit, 2000; 22: 131-6.

[57] Ioannides C. Pharmacokinetic interactions between herbal remedies and medicinal drugs. Xenobiotica, 2002; 32: 451-78.

[58] Chen AC, Donovan SM. Genistein at a concentration present in soy infant formula inhibits Caco2BBe cell proliferation by causing G2/M cell cycle arrest. J Nutr, 2004; 134: 1303-8.

[59] Horie N, Hirabayashi N, Takahashi Y, Miyauchi Y, Taguchi H, Takeishi K. Synergistic effect of green tea catechins on cell growth and apoptosis induction in gastric carcinoma cells. Biol Pharm Bull, 2005; 28: 574-9.

[60] Kaneuchi M, Sasaki M, Tanaka Y, Sakuragi N, Fujimoto S, Dahiya R. Quercetin regulates growth of Ishikawa cells through the suppression of EGF and cyclin D1. Int J Oncol, 2003; 22: 159-64. 
[61] Kumi-Diaka J, Sanderson NA, Hall A. The mediating role of caspase-3 protease in the intracellular mechanism of genistein-induced apoptosis in human prostatic carcinoma cell lines, DU145 and LNCaP. Biol Cell, 2000; 92: 595-604.

[62] Nomura M, Ma W, Chen N, Bode AM, Dong Z. Inhibition of 12-O-tetradecanoylphorbol-13acetate-induced NF-kappaB activation by tea polyphenols, (-)-epigallocatechin gallate and theaflavins. Carcinogenesis, 2000; 21: 1885-90.

[63] Afaq F, Adhami VM, Ahmad N, Mukhtar H. Inhibition of ultraviolet B-mediated activation of nuclear factor kappaB in normal human epidermal keratinocytes by green tea Constituent (-)epigallocatechin-3-gallate. Oncogene, 2003; 22: 1035-44.

[64] Cleary JM, Shapiro GI. Development of phosphoinositide-3 kinase pathway inhibitors for advanced cancer. Curr Oncol Rep, 2010; 12: 87-94.

[65] Kim J, Zhang X, Rieger-Christ KM, Summerhayes IC, Wazer DE, Paulson KE, Yee AS. Suppression of Wnt signaling by the green tea compound (-)-epigallocatechin 3-gallate (EGCG) in invasive breast cancer cells. Requirement of the transcriptional repressor HBP1. J Biol Chem, 2006; 281: 10865-75.

[66] Kitagawa S, Nabekura T, Kamiyama S. Inhibition of P-glycoprotein function by tea catechins in KB-C2 cells. J Pharm Pharmacol, 2004; 56: 1001-5.

[67] Roninson IB, Chin JE, Choi KG, Gros P, Housman DE, Fojo A, Shen DW, Gottesman MM, Pastan I. Isolation of human mdr DNA sequences amplified in multidrug-resistant $\mathrm{KB}$ carcinoma cells. Proc Natl Acad Sci U S A, 1986; 83: 4538-42.

[68] Akiyama S, Fojo A, Hanover JA, Pastan I, Gottesman MM. Isolation and genetic characterization of human KB cell lines resistant to multiple drugs. Somat Cell Mol Genet, 1985; 11: 117-26.

[69] Korkina LG. Phenylpropanoids as naturally occurring antioxidants: from plant defense to human health. Cell Mol Biol (Noisy-le-grand), 2007; 53: 15-25.

[70] Korkina L, Kostyuk V, De Luca C, Pastore S. Plant phenylpropanoids as emerging antiinflammatory agents. Mini Rev Med Chem, 2011; 11: 823-35.

[71] Saarinen NM, Huovinen R, Warri A, Makela SI, Valentin-Blasini L, Sjoholm R, Ammala J, Lehtila R, Eckerman C, Collan YU, Santti RS. Enterolactone inhibits the growth of 7,12dimethylbenz(a)anthracene-induced mammary carcinomas in the rat. Mol Cancer Ther, 2002; 1: 869-76.

[72] Bergman Jungestrom M, Thompson LU, Dabrosin C. Flaxseed and its lignans inhibit estradiolinduced growth, angiogenesis, and secretion of vascular endothelial growth factor in human breast cancer xenografts in vivo. Clin Cancer Res, 2007; 13: 1061-7.

[73] Lindahl G, Saarinen N, Abrahamsson A, Dabrosin C. Tamoxifen, flaxseed, and the lignan enterolactone increase stroma- and cancer cell-derived IL-1Ra and decrease tumor angiogenesis in estrogen-dependent breast cancer. Cancer Res, 2011; 71: 51-60.

[74] Huang M, Jin J, Sun H, Liu GT. Reversal of P-glycoprotein-mediated multidrug resistance of cancer cells by five schizandrins isolated from the Chinese herb Fructus Schizandrae. Cancer Chemother Pharmacol, 2008; 62: 1015-26.

[75] Slanina J, Pachnikova G, Carnecka M, Porubova Koubikova L, Adamkova L, Humpa O, Smejkal $\mathrm{K}$, Slaninova I. Identification of key structural characteristics of Schisandra chinensis lignans involved in P-glycoprotein inhibition. J Nat Prod, 2014; 77: 2255-63.

[76] Qin XL, Chen X, Wang Y, Xue XP, Li JL, Wang XD, Zhong GP, Wang CX, Yang H, Huang M, Bi HC. In vivo to in vitro effects of six bioactive lignans of Wuzhi tablet (Schisandra sphenanthera extract) on the CYP3A/P-glycoprotein-mediated absorption and metabolism of tacrolimus. Drug Metab Dispos, 2014; 42: 193-9.

[77] Lee CK, Choi JS. Effects of silibinin, inhibitor of CYP3A4 and P-glycoprotein in vitro, on the pharmacokinetics of paclitaxel after oral and intravenous administration in rats. Pharmacology, 2010; 85: 350-6.

[78] Zhou L, Liu P, Chen B, Wang Y, Wang X, Chiriva Internati M, Wachtel MS, Frezza EE. Silibinin restores paclitaxel sensitivity to paclitaxel-resistant human ovarian carcinoma cells. Anticancer Res, 2008; 28: 1119-27.

[79] Leite DF, Kassuya CA, Mazzuco TL, Silvestre A, de Melo LV, Rehder VL, Rumjanek VM, Calixto JB. The cytotoxic effect and the multidrug resistance reversing action of lignans from Phyllanthus amarus. Planta Med, 2006; 72: 1353-8. 
[80] Brand S, Holscher D, Schierhorn A, Svatos A, Schroder J, Schneider B. A type III polyketide synthase from Wachendorfia thyrsiflora and its role in diarylheptanoid and phenylphenalenone biosynthesis. Planta, 2006; 224: 413-28.

[81] Munde T, Brand S, Hidalgo W, Maddula RK, Svatos A, Schneider B. Biosynthesis of tetraoxygenated phenylphenalenones in Wachendorfia thyrsiflora. Phytochemistry, 2013; 91: 16576.

[82] Tung NH, Kim SK, Ra JC, Zhao YZ, Sohn DH, Kim YH. Antioxidative and hepatoprotective diarylheptanoids from the bark of Alnus japonica. Planta Med, 2010; 76: 626-9.

[83] Lai YC, Chen CK, Lin WW, Lee SS. A comprehensive investigation of anti-inflammatory diarylheptanoids from the leaves of Alnus formosana. Phytochemistry, 2012; 73: 84-94.

[84] Tung NH, Kwon HJ, Kim JH, Ra JC, Ding Y, Kim JA, Kim YH. Anti-influenza diarylheptanoids from the bark of Alnus japonica. Bioorg Med Chem Lett, 2010; 20: 1000-3.

[85] Choi SE, Kim KH, Kwon JH, Kim SB, Kim HW, Lee MW. Cytotoxic activities of diarylheptanoids from Alnus japonica. Arch Pharm Res, 2008; 31: 1287-9.

[86] Mshvildadze V, Legault J, Lavoie S, Gauthier C, Pichette A. Anticancer diarylheptanoid glycosides from the inner bark of Betula papyrifera. Phytochemistry, 2007; 68: 2531-6.

[87] Matsuda H, Ishikado A, Nishida N, Ninomiya K, Fujiwara H, Kobayashi Y, Yoshikawa M. Hepatoprotective, superoxide scavenging, and antioxidative activities of aromatic constituents from the bark of Betula platyphylla var. japonica. Bioorg Med Chem Lett, 1998; 8: 2939-44.

[88] Lee MA, Lee HK, Kim SH, Kim YC, Sung SH. Chemical constituents of Alnus firma and their inhibitory activity on lipopolysaccharide-induced nitric oxide production in BV2 microglia. Planta Med, 2010; 76: 1007-10.

[89] Chearwae W, Anuchapreeda S, Nandigama K, Ambudkar SV, Limtrakul P. Biochemical mechanism of modulation of human P-glycoprotein (ABCB1) by curcumin I, II, and III purified from Turmeric powder. Biochem Pharmacol, 2004; 68: 2043-52.

[90] Bisht K, Wagner KH, Bulmer AC. Curcumin, resveratrol and flavonoids as anti-inflammatory, cyto- and DNA-protective dietary compounds. Toxicology, 2010; 278: 88-100.

[91] Shishodia S, Singh T, Chaturvedi MM. Modulation of transcription factors by curcumin. Adv Exp Med Biol, 2007; 595: 127-48.

[92] Aggarwal BB, Kumar A, Bharti AC. Anticancer potential of curcumin: preclinical and clinical studies. Anticancer Res, 2003; 23: 363-98.

[93] Aggarwal BB, Harikumar KB. Potential therapeutic effects of curcumin, the anti-inflammatory agent, against neurodegenerative, cardiovascular, pulmonary, metabolic, autoimmune and neoplastic diseases. Int J Biochem Cell Biol, 2009; 41: 40-59.

[94] Gupta SC, Patchva S, Koh W, Aggarwal BB. Discovery of curcumin, a component of golden spice, and its miraculous biological activities. Clin Exp Pharmacol Physiol, 2012; 39: 283-99.

[95] Chearwae W, Wu CP, Chu HY, Lee TR, Ambudkar SV, Limtrakul P. Curcuminoids purified from turmeric powder modulate the function of human multidrug resistance protein 1 (ABCC1). Cancer Chemother Pharmacol, 2006; 57: 376-88.

[96] Andjelkovic T, Pesic M, Bankovic J, Tanic N, Markovic ID, Ruzdijic S. Synergistic effects of the purine analog sulfinosine and curcumin on the multidrug resistant human non-small cell lung carcinoma cell line (NCI-H460/R). Cancer Biol Ther, 2008; 7: 1024-32.

[97] Limtrakul P, Chearwae W, Shukla S, Phisalphong C, Ambudkar SV. Modulation of function of three $\mathrm{ABC}$ drug transporters, $\mathrm{P}$-glycoprotein $(\mathrm{ABCB} 1)$, mitoxantrone resistance protein $(\mathrm{ABCG} 2)$ and multidrug resistance protein 1 (ABCC1) by tetrahydrocurcumin, a major metabolite of curcumin. Mol Cell Biochem, 2007; 296: 85-95.

[98] Chearwae W, Shukla S, Limtrakul P, Ambudkar SV. Modulation of the function of the multidrug resistance-linked ATP-binding cassette transporter ABCG2 by the cancer chemopreventive agent curcumin. Mol Cancer Ther, 2006; 5: 1995-2006.

[99] Aggarwal BB, Van Kuiken ME, Iyer LH, Harikumar KB, Sung B. Molecular targets of nutraceuticals derived from dietary spices: potential role in suppression of inflammation and tumorigenesis. Exp Biol Med (Maywood), 2009; 234: 825-49.

[100] Singh S, Aggarwal BB. Activation of transcription factor NF-kappa B is suppressed by curcumin (diferuloylmethane) [corrected]. J Biol Chem, 1995; 270: 24995-5000. 
[101] Chun KS, Keum YS, Han SS, Song YS, Kim SH, Surh YJ. Curcumin inhibits phorbol esterinduced expression of cyclooxygenase-2 in mouse skin through suppression of extracellular signal-regulated kinase activity and NF-kappaB activation. Carcinogenesis, 2003; 24: 1515-24.

[102] Park CH, Hahm ER, Park S, Kim HK, Yang CH. The inhibitory mechanism of curcumin and its derivative against beta-catenin/Tcf signaling. FEBS Lett, 2005; 579: 2965-71.

[103] Jaiswal AS, Marlow BP, Gupta N, Narayan S. Beta-catenin-mediated transactivation and cell-cell adhesion pathways are important in curcumin (diferuylmethane)-induced growth arrest and apoptosis in colon cancer cells. Oncogene, 2002; 21: 8414-27.

[104] Guertin DA, Sabatini DM. Defining the role of mTOR in cancer. Cancer Cell, 2007; 12: 9-22.

[105] Beevers CS, Li F, Liu L, Huang S. Curcumin inhibits the mammalian target of rapamycinmediated signaling pathways in cancer cells. Int J Cancer, 2006; 119: 757-64.

[106] Yu S, Shen G, Khor TO, Kim JH, Kong AN. Curcumin inhibits Akt/mammalian target of rapamycin signaling through protein phosphatase-dependent mechanism. Mol Cancer Ther, 2008; 7: 2609-20.

[107] Nabekura T, Kamiyama S, Kitagawa S. Effects of dietary chemopreventive phytochemicals on Pglycoprotein function. Biochem Biophys Res Commun, 2005; 327: 866-70.

[108] Cheng AL, Hsu CH, Lin JK, Hsu MM, Ho YF, Shen TS, Ko JY, Lin JT, Lin BR, Ming-Shiang W, Yu HS, Jee SH, Chen GS, Chen TM, Chen CA, Lai MK, Pu YS, Pan MH, Wang YJ, Tsai CC, Hsieh CY. Phase I clinical trial of curcumin, a chemopreventive agent, in patients with high-risk or pre-malignant lesions. Anticancer Res, 2001; 21: 2895-900.

[109] Deodhar SD, Sethi R, Srimal RC. Preliminary study on antirheumatic activity of curcumin (diferuloyl methane). Indian J Med Res, 1980; 71: 632-4.

[110] Lal B, Kapoor AK, Asthana OP, Agrawal PK, Prasad R, Kumar P, Srimal RC. Efficacy of curcumin in the management of chronic anterior uveitis. Phytother Res, 1999; 13: 318-22.

[111] Hsu CH, Cheng AL. Clinical studies with curcumin. Adv Exp Med Biol, 2007; 595: 471-80.

[112] Heng MC, Song MK, Harker J, Heng MK. Drug-induced suppression of phosphorylase kinase activity correlates with resolution of psoriasis as assessed by clinical, histological and immunohistochemical parameters. Br J Dermatol, 2000; 143: 937-49.

[113] Dhillon N, Aggarwal BB, Newman RA, Wolff RA, Kunnumakkara AB, Abbruzzese JL, Ng CS, Badmaev V, Kurzrock R. Phase II trial of curcumin in patients with advanced pancreatic cancer. Clin Cancer Res, 2008; 14: 4491-9.

[114] Bisht S, Feldmann G, Soni S, Ravi R, Karikar C, Maitra A. Polymeric nanoparticle-encapsulated curcumin ("nanocurcumin"): a novel strategy for human cancer therapy. J Nanobiotechnology, 2007; 5: 3 .

[115] Shaikh J, Ankola DD, Beniwal V, Singh D, Kumar MN. Nanoparticle encapsulation improves oral bioavailability of curcumin by at least 9-fold when compared to curcumin administered with piperine as absorption enhancer. Eur J Pharm Sci, 2009; 37: 223-30.

[116] Mosley CA, Liotta DC, Snyder JP. Highly active anticancer curcumin analogues. Adv Exp Med Biol, 2007; 595: 77-103.

[117] Li L, Braiteh FS, Kurzrock R. Liposome-encapsulated curcumin: in vitro and in vivo effects on proliferation, apoptosis, signaling, and angiogenesis. Cancer, 2005; 104: 1322-31.

[118] Shoba G, Joy D, Joseph T, Majeed M, Rajendran R, Srinivas PS. Influence of piperine on the pharmacokinetics of curcumin in animals and human volunteers. Planta Med, 1998; 64: 353-6.

[119] Shimizu B. 2-Oxoglutarate-dependent dioxygenases in the biosynthesis of simple coumarins. Front Plant Sci, 2014; 5: 549.

[120] Jevtić V, Pešić M, G. R, Vuković N, Sukdolak S, Klisurić O, Podolski-Renić A, Tanić N, Trifunović S. Synthesis, characterization and cytotoxicity of a new palladium(II) complex with a coumarin-derived ligand. Crystal structure of 4-hydroxy-3-(1-(p-tolylimino)ethyl)-2H-chromen-2one-palladium(II) complex. J Mol Struct, 2013; 1040: 216-220.

[121] Iranshahi M, Barthomeuf C, Bayet-Robert M, Chollet P, Davoodi D, Piacente S, Rezaee R, Sahebkar A. Drimane-Type Sesquiterpene Coumarins from Ferula gummosa Fruits Enhance Doxorubicin Uptake in Doxorubicin-Resistant Human Breast Cancer Cell Line. J Tradit Complement Med, 2014; 4: 118-25.

[122] Shen X, Chen G, Zhu G, Fong WF. (+/-)-3'-O, 4'-O-dicynnamoyl-cis-khellactone, a derivative of (+/-)-praeruptorin A, reverses P-glycoprotein mediated multidrug resistance in cancer cells. Bioorg Med Chem, 2006; 14: 7138-45. 
[123] Shen X, Chen G, Zhu G, Cai J, Wang L, Hu Y, Fong WF. 3'-O, 4'-O-aromatic acyl substituted 7,8pyranocoumarins: a new class of P-glycoprotein modulators. J Pharm Pharmacol, 2012; 64: 90100.

[124] Iwanaga K, Hayashi M, Hamahata Y, Miyazaki M, Shibano M, Taniguchi M, Baba K, Kakemi M. Furanocoumarin derivatives in Kampo extract medicines inhibit cytochrome P450 3A4 and Pglycoprotein. Drug Metab Dispos, 2010; 38: 1286-94.

[125] Iwanaga K, Yoneda S, Hamahata Y, Miyazaki M, Shibano M, Taniguchi M, Baba K, Kakemi M. Inhibitory effects of furanocoumarin derivatives in Kampo extract medicines on P-glycoprotein at the blood-brain barrier. Biol Pharm Bull, 2011; 34: 1246-51.

[126] Kim SO, Chun KS, Kundu JK, Surh YJ. Inhibitory effects of [6]-gingerol on PMA-induced COX2 expression and activation of NF-kappaB and p38 MAPK in mouse skin. Biofactors, 2004; 21 : 27-31.

[127] Lee SH, Cekanova M, Baek SJ. Multiple mechanisms are involved in 6-gingerol-induced cell growth arrest and apoptosis in human colorectal cancer cells. Mol Carcinog, 2008; 47: 197-208.

[128] Banthorpe D. Classification of Terpenoids and General Procedures for Their Characterization. In: ed.^eds., Methods in Plant Biochemistry: Terpenoids. Academic Press: London, 1991; pp. 1-41.

[129] Davis E, Croteau R. Cyclization Enzymes in the Biosynthesis of Monoterpenes, Sesquiterpenes, and Diterpenes. In: ed.^eds., Topics in Current Chemistry: Biosynthesis: Aromatic Polyketides, Isoprenoids, Alkaloids. Springer: New York, 2000; pp. 53-95.

[130] Gershenzon J, Kreis W. Biochemistry of Terpenoids. In: ed.^eds., Biochemistry of Plant Secondary Metabolism, Annual Plant Reviews. Sheffield Academic Press, CRC Press: Sheffield, Boca Raton, 1999; pp. 222-299.

[131] Fischedick JT, Standiford M, Johnson DA, Johnson JA. Structure activity relationship of phenolic diterpenes from Salvia officinalis as activators of the nuclear factor E2-related factor 2 pathway. Bioorg Med Chem, 2013; 21: 2618-22.

[132] Spivey AC, Weston M, Woodhead S. Celastraceae sesquiterpenoids: biological activity and synthesis. Chem Soc Rev, 2002; 31: 43-59.

[133] Cortes-Selva F, Jimenez IA, Munoz-Martinez F, Campillo M, Bazzocchi IL, Pardo L, Ravelo AG, Castanys S, Gamarro F. Dihydro-beta-agarofuran sesquiterpenes: a new class of reversal agents of the multidrug resistance phenotype mediated by P-glycoprotein in the protozoan parasite Leishmania. Curr Pharm Des, 2005; 11: 3125-39.

[134] Munoz-Martinez F, Lu P, Cortes-Selva F, Perez-Victoria JM, Jimenez IA, Ravelo AG, Sharom FJ, Gamarro F, Castanys S. Celastraceae sesquiterpenes as a new class of modulators that bind specifically to human P-glycoprotein and reverse cellular multidrug resistance. Cancer Res, 2004; 64: 7130-8.

[135] Lanzotti V, Xiao J. Natural Products in Cancer Prevention and Therapy, a selection of topics presented in the 2nd Edition PSE Symposium (Naples, Italy, 25th to 28th of June 2013). Anticancer Agents Med Chem, 2014; 14: 1313-4.

[136] Molnar J, Gyemant N, Tanaka M, Hohmann J, Bergmann-Leitner E, Molnar P, Deli J, Didiziapetris R, Ferreira MJ. Inhibition of multidrug resistance of cancer cells by natural diterpenes, triterpenes and carotenoids. Curr Pharm Des, 2006; 12: 287-311.

[137] Duarte N, Varga A, Cherepnev G, Radics R, Molnar J, Ferreira MJ. Apoptosis induction and modulation of P-glycoprotein mediated multidrug resistance by new macrocyclic lathyrane-type diterpenoids. Bioorg Med Chem, 2007; 15: 546-54.

[138] Lage H, Duarte N, Coburger C, Hilgeroth A, Ferreira MJ. Antitumor activity of terpenoids against classical and atypical multidrug resistant cancer cells. Phytomedicine, 2010; 17: 441-8.

[139] Abdallah HM, Al-Abd AM, El-Dine RS, El-Halawany AM. P-glycoprotein inhibitors of natural origin as potential tumor chemo-sensitizers: A review. J Adv Res, 2015; 6: 45-62.

[140] Wellwood CR, Cole RA. Relevance of carnosic acid concentrations to the selection of rosemary, Rosmarinus officinalis (L.), accessions for optimization of antioxidant yield. J Agric Food Chem, 2004; 52: 6101-7.

[141] Yu MH, Choi JH, Chae IG, Im HG, Yang SA, More K, Lee IS, Lee J. Suppression of LPS-induced inflammatory activities by Rosmarinus officinalis L. Food Chem, 2013; 136: 1047-54.

[142] Huang MT, Ho CT, Wang ZY, Ferraro T, Lou YR, Stauber K, Ma W, Georgiadis C, Laskin JD, Conney AH. Inhibition of skin tumorigenesis by rosemary and its constituents carnosol and ursolic acid. Cancer Res, 1994; 54: 701-8. 
[143] Huang SC, Ho CT, Lin-Shiau SY, Lin JK. Carnosol inhibits the invasion of B16/F10 mouse melanoma cells by suppressing metalloproteinase- 9 through down-regulating nuclear factor-kappa B and c-Jun. Biochem Pharmacol, 2005; 69: 221-32.

[144] Lo AH, Liang YC, Lin-Shiau SY, Ho CT, Lin JK. Carnosol, an antioxidant in rosemary, suppresses inducible nitric oxide synthase through down-regulating nuclear factor-kappaB in mouse macrophages. Carcinogenesis, 2002; 23: 983-91.

[145] Moran AE, Carothers AM, Weyant MJ, Redston M, Bertagnolli MM. Carnosol inhibits betacatenin tyrosine phosphorylation and prevents adenoma formation in the C57BL/6J/Min/+ (Min/+) mouse. Cancer Res, 2005; 65: 1097-104.

[146] Nabekura T, Yamaki T, Hiroi T, Ueno K, Kitagawa S. Inhibition of anticancer drug efflux transporter P-glycoprotein by rosemary phytochemicals. Pharmacol Res, 2010; 61: 259-63.

[147] Bednarczyk-Cwynar B, Zaprutko L. Recent advances in synthesis and biological activity of triterpenic acylated oximes. Phytochem Rev, 2015; 14: 203-231.

[148] Yeung M, Che C. A review of presence of oleanolic acid in natural products. Natura Proda Medica, 2009: 77-290.

[149] Paszel A, Rubis B, Bednarczyk-Cwynar B, Zaprutko L, Kaczmarek M, Hofmann J, Rybczynska M. Oleanolic acid derivative methyl 3,11-dioxoolean-12-en-28-olate targets multidrug resistance related to ABCB1. Pharmacol Rep, 2011; 63: 1500-17.

[150] Kim SW, Kwon HY, Chi DW, Shim JH, Park JD, Lee YH, Pyo S, Rhee DK. Reversal of Pglycoprotein-mediated multidrug resistance by ginsenoside $\operatorname{Rg}(3)$. Biochem Pharmacol, 2003; 65: $75-82$.

[151] Yang LQ, Wang B, Gan H, Fu ST, Zhu XX, Wu ZN, Zhan DW, Gu RL, Dou GF, Meng ZY. Enhanced oral bioavailability and anti-tumour effect of paclitaxel by 20 (s)-ginsenoside $\mathrm{Rg} 3$ in vivo. Biopharm Drug Dispos, 2012; 33: 425-36.

[152] Zhang J, Zhou F, Wu X, Gu Y, Ai H, Zheng Y, Li Y, Zhang X, Hao G, Sun J, Peng Y, Wang G. 20(S)-ginsenoside Rh2 noncompetitively inhibits P-glycoprotein in vitro and in vivo: a case for herb-drug interactions. Drug Metab Dispos, 2010; 38: 2179-87.

[153] Zhang J, Lu M, Zhou F, Sun H, Hao G, Wu X, Wang G. Key role of nuclear factor-kappaB in the cellular pharmacokinetics of adriamycin in MCF-7/Adr cells: the potential mechanism for synergy with 20(S)-ginsenoside Rh2. Drug Metab Dispos, 2012; 40: 1900-8.

[154] Roy A, Saraf S. Limonoids: overview of significant bioactive triterpenes distributed in plants kingdom. Biol Pharm Bull, 2006; 29: 191-201.

[155] Berhow MA, Hasegawa S, Manners GD. Citrus Limonoids: Functional Chemicals in Agriculture and Food. American Chemical Society Washington DC 2000.

[156] Poulose SM, Harris ED, Patil BS. Citrus limonoids induce apoptosis in human neuroblastoma cells and have radical scavenging activity. J Nutr, 2005; 135: 870-7.

[157] Berhow MA, Omura M, Ohta H, Ozaki Y, Hasegawa S. Limonoids in Seeds of 3 Citrus Hybrids Related to Citrus ichangensis. Phytochemistry, 1994: 923-925.

[158] Silalahi J. Anticancer and health protective properties of citrus fruit components. Asia Pac J Clin Nutr, 2002; 11: 79-84.

[159] Tanaka T, Kohno H, Tsukio Y, Honjo S, Tanino M, Miyake M, Wada K. Citrus limonoids obacunone and limonin inhibit azoxymethane-induced colon carcinogenesis in rats. Biofactors, 2000; 13: 213-8.

[160] Katan MB, Grundy SM, Jones P, Law M, Miettinen T, Paoletti R. Efficacy and safety of plant stanols and sterols in the management of blood cholesterol levels. Mayo Clin Proc, 2003; 78: 965 78.

[161] Awad AB, Fink CS. Phytosterols as anticancer dietary components: evidence and mechanism of action. J Nutr, 2000; 130: 2127-30.

[162] El-Readi MZ, Hamdan D, Farrag N, El-Shazly A, Wink M. Inhibition of P-glycoprotein activity by limonin and other secondary metabolites from Citrus species in human colon and leukaemia cell lines. Eur J Pharmacol, 2010; 626: 139-45.

[163] Wink M. Evolutionary advantage and molecular modes of action of multi-component mixtures used in phytomedicine. Curr Drug Metab, 2008; 9: 996-1009.

[164] Brobst DE, Ding X, Creech KL, Goodwin B, Kelley B, Staudinger JL. Guggulsterone activates multiple nuclear receptors and induces CYP3A gene expression through the pregnane $\mathrm{X}$ receptor. J Pharmacol Exp Ther, 2004; 310: 528-35. 
[165] Urquhart BL, Tirona RG, Kim RB. Nuclear receptors and the regulation of drug-metabolizing enzymes and drug transporters: implications for interindividual variability in response to drugs. $\mathbf{J}$ Clin Pharmacol, 2007; 47: 566-78.

[166] Shishodia S, Aggarwal BB. Guggulsterone inhibits NF-kappaB and IkappaBalpha kinase activation, suppresses expression of anti-apoptotic gene products, and enhances apoptosis. J Biol Chem, 2004; 279: 47148-58.

[167] Nabekura T, Yamaki T, Ueno K, Kitagawa S. Effects of plant sterols on human multidrug transporters ABCB1 and ABCC1. Biochem Biophys Res Commun, 2008; 369: 363-8.

[168] Zhu HJ, Wang JS, Markowitz JS, Donovan JL, Gibson BB, Gefroh HA, Devane CL. Characterization of P-glycoprotein inhibition by major cannabinoids from marijuana. J Pharmacol Exp Ther, 2006; 317: 850-7.

[169] Feinshtein V, Erez O, Ben-Zvi Z, Erez N, Eshkoli T, Sheizaf B, Sheiner E, Huleihel M, Holcberg G. Cannabidiol changes P-gp and BCRP expression in trophoblast cell lines. PeerJ, 2013; 1: e153.

[170] Zdarilova A, Malikova J, Dvorak Z, Ulrichová J, Šimánek V. Quaternary Isoquinoline Alkaloids Sanguinarine and Chelerythrine. In Vitro and in Vivo Effects. Chemické Listy, 2006: 30-41.

[171] Fu LW, Deng ZA, Pan QC, Fan W. Screening and discovery of novel MDR modifiers from naturally occurring bisbenzylisoquinoline alkaloids. Anticancer Res, 2001; 21: 2273-80.

[172] He L, Liu GQ. Effects of Various Principles from Chinese Herbal Medicine on Rhodamine123 Accumulation in Brain Capillary Endothelial Cells. Acta Pharmacol Sin, 2002: 591-596.

[173] Moller M, Weiss J, Wink M. Reduction of cytotoxicity of the alkaloid emetine through Pglycoprotein (MDR1/ABCB1) in human Caco-2 cells and leukemia cell lines. Planta Med, 2006; 72: 1121-6.

[174] El-Readi MZ, Eid S, Ashour ML, Tahrani A, Wink M. Modulation of multidrug resistance in cancer cells by chelidonine and Chelidonium majus alkaloids. Phytomedicine, 2013; 20: 282-94.

[175] Adhami VM, Aziz MH, Mukhtar H, Ahmad N. Activation of prodeath Bcl-2 family proteins and mitochondrial apoptosis pathway by sanguinarine in immortalized human HaCaT keratinocytes. Clin Cancer Res, 2003; 9: 3176-82.

[176] Adhami VM, Aziz MH, Reagan-Shaw SR, Nihal M, Mukhtar H, Ahmad N. Sanguinarine causes cell cycle blockade and apoptosis of human prostate carcinoma cells via modulation of cyclin kinase inhibitor-cyclin-cyclin-dependent kinase machinery. Mol Cancer Ther, 2004; 3: 933-40.

[177] Malikova J, Zdarilova A, Hlobilkova A. Effects of sanguinarine and chelerythrine on the cell cycle and apoptosis. Biomed Pap Med Fac Univ Palacky Olomouc Czech Repub, 2006; 150: 5-12.

[178] Ding Z, Tang SC, Weerasinghe P, Yang X, Pater A, Liepins A. The alkaloid sanguinarine is effective against multidrug resistance in human cervical cells via bimodal cell death. Biochem Pharmacol, 2002; 63: 1415-21.

[179] Moller M, Herzer K, Wenger T, Herr I, Wink M. The alkaloid emetine as a promising agent for the induction and enhancement of drug-induced apoptosis in leukemia cells. Oncol Rep, 2007; 18: 737-44.

[180] Moller M, Wink M. Characteristics of apoptosis induction by the alkaloid emetine in human tumour cell lines. Planta Med, 2007; 73: 1389-96.

[181] Rosenkranz V, Wink M. Alkaloids induce programmed cell death in bloodstream forms of trypanosomes (Trypanosoma b. brucei). Molecules, 2008; 13: 2462-73.

[182] Mi Q, Cui B, Silva GL, Lantvit D, Lim E, Chai H, You M, Hollingshead MG, Mayo JG, Kinghorn AD, Pezzuto JM. Pervilleine A, a novel tropane alkaloid that reverses the multidrug-resistance phenotype. Cancer Res, 2001; 61: 4030-7.

[183] Mi Q, Cui B, Silva GL, Lantvit D, Lim E, Chai H, Hollingshead MG, Mayo JG, Kinghorn AD, Pezzuto JM. Pervilleines B and C, new tropane alkaloid aromatic esters that reverse the multidrugresistance in the hollow fiber assay. Cancer Lett, 2002; 184: 13-20.

[184] Mi Q, Cui B, Lantvit D, Reyes-Lim E, Chai H, Pezzuto JM, Kinghorn AD, Swanson SM. Pervilleine F, a new tropane alkaloid aromatic ester that reverses multidrug resistance. Anticancer Res, 2003; 23: 3607-15.

[185] Huang Y, Blower PE, Yang C, Barbacioru C, Dai Z, Zhang Y, Xiao JJ, Chan KK, Sadee W. Correlating gene expression with chemical scaffolds of cytotoxic agents: ellipticines as substrates and inhibitors of MDR1. Pharmacogenomics J, 2005; 5: 112-25.

[186] Stiborova M, Manhartova Z, Hodek P, Adam V, Kizek R, Frei E. Formation of DNA adducts by ellipticine and its micellar form in rats - a comparative study. Sensors (Basel), 2014; 14: 22982-97. 
[187] Singh S, Natarajan K, Aggarwal BB. Capsaicin (8-methyl-N-vanillyl-6-nonenamide) is a potent inhibitor of nuclear transcription factor-kappa B activation by diverse agents. J Immunol, 1996; 157: 4412-20.

[188] Han SS, Keum YS, Seo HJ, Chun KS, Lee SS, Surh YJ. Capsaicin suppresses phorbol esterinduced activation of NF-kappaB/Rel and AP-1 transcription factors in mouse epidermis. Cancer Lett, 2001; 164: 119-26.

[189] Hu GP, Yuan J, Sun L, She ZG, Wu JH, Lan XJ, Zhu X, Lin YC, Chen SP. Statistical research on marine natural products based on data obtained between 1985 and 2008. Mar Drugs, 2011; 9: 51425.

[190] Hu Y, Chen J, Hu G, Yu J, Zhu X, Lin Y, Chen S, Yuan J. Statistical research on the bioactivity of new marine natural products discovered during the 28 years from 1985 to 2012. Mar Drugs, 2015; 13: 202-21.

[191] Aoki S, Chen ZS, Higasiyama K, Setiawan A, Akiyama S, Kobayashi M. Reversing effect of agosterol A, a spongean sterol acetate, on multidrug resistance in human carcinoma cells. Jpn J Cancer Res, 2001; 92: 886-95.

[192] Chen ZS, Aoki S, Komatsu M, Ueda K, Sumizawa T, Furukawa T, Okumura H, Ren XQ, Belinsky MG, Lee K, Kruh GD, Kobayashi M, Akiyama S. Reversal of drug resistance mediated by multidrug resistance protein (MRP) 1 by dual effects of agosterol A on MRP1 function. Int J Cancer, 2001; 93: 107-13.

[193] Rinehart KL. Antitumor compounds from tunicates. Med Res Rev, 2000; 20: 1-27.

[194] Zewail-Foote M, Hurley LH. Ecteinascidin 743: a minor groove alkylator that bends DNA toward the major groove. J Med Chem, 1999; 42: 2493-7.

[195] Nebl T, Pestonjamasp KN, Leszyk JD, Crowley JL, Oh SW, Luna EJ. Proteomic analysis of a detergent-resistant membrane skeleton from neutrophil plasma membranes. J Biol Chem, 2002; 277: 43399-409.

[196] Kanzaki A, Takebayashi Y, Ren XQ, Miyashita H, Mori S, Akiyama S, Pommier Y. Overcoming multidrug drug resistance in P-glycoprotein/MDR1-overexpressing cell lines by ecteinascidin 743 . Mol Cancer Ther, 2002; 1: 1327-34.

[197] Amador ML, Jimeno J, Paz-Ares L, Cortes-Funes H, Hidalgo M. Progress in the development and acquisition of anticancer agents from marine sources. Ann Oncol, 2003; 14: 1607-15.

[198] Jain S, Laphookhieo S, Shi Z, Fu LW, Akiyama S, Chen ZS, Youssef DT, van Soest RW, El Sayed KA. Reversal of P-glycoprotein-mediated multidrug resistance by sipholane triterpenoids. J Nat Prod, 2007; 70: 928-31.

[199] Jain S, Abraham I, Carvalho P, Kuang YH, Shaala LA, Youssef DT, Avery MA, Chen ZS, El Sayed KA. Sipholane triterpenoids: chemistry, reversal of ABCB1/P-glycoprotein-mediated multidrug resistance, and pharmacophore modeling. J Nat Prod, 2009; 72: 1291-8.

[200] Shi Z, Peng XX, Kim IW, Shukla S, Si QS, Robey RW, Bates SE, Shen T, Ashby CR, Jr., Fu LW, Ambudkar SV, Chen ZS. Erlotinib (Tarceva, OSI-774) antagonizes ATP-binding cassette subfamily B member 1 and ATP-binding cassette subfamily G member 2-mediated drug resistance. Cancer Res, 2007; 67: 11012-20.

[201] Abraham I, El Sayed K, Chen ZS, Guo H. Current status on marine products with reversal effect on cancer multidrug resistance. Mar Drugs, 2012; 10: 2312-21.

[202] Abraham I, Jain S, Wu CP, Khanfar MA, Kuang Y, Dai CL, Shi Z, Chen X, Fu L, Ambudkar SV, El Sayed K, Chen ZS. Marine sponge-derived sipholane triterpenoids reverse P-glycoprotein (ABCB1)-mediated multidrug resistance in cancer cells. Biochem Pharmacol, 2010; 80: 1497-506.

[203] Kraft AS, Smith JB, Berkow RL. Bryostatin, an activator of the calcium phospholipid-dependent protein kinase, blocks phorbol ester-induced differentiation of human promyelocytic leukemia cells HL-60. Proc Natl Acad Sci U S A, 1986; 83: 1334-8.

[204] Isakov N, Galron D, Mustelin T, Pettit GR, Altman A. Inhibition of phorbol ester-induced T cell proliferation by bryostatin is associated with rapid degradation of protein kinase C. J Immunol, 1993; 150: 1195-204.

[205] Chambers TC, McAvoy EM, Jacobs JW, Eilon G. Protein kinase C phosphorylates P-glycoprotein in multidrug resistant human KB carcinoma cells. J Biol Chem, 1990; 265: 7679-86.

[206] Smith CD, Zilfou JT, Stratmann K, Patterson GM, Moore RE. Welwitindolinone analogues that reverse P-glycoprotein-mediated multiple drug resistance. Mol Pharmacol, 1995; 47: 241-7. 
[207] McGrogan BT, Gilmartin B, Carney DN, McCann A. Taxanes, microtubules and chemoresistant breast cancer. Biochim Biophys Acta, 2008; 1785: 96-132.

[208] Wani MC, Taylor HL, Wall ME, Coggon P, McPhail AT. Plant antitumor agents. VI. The isolation and structure of taxol, a novel antileukemic and antitumor agent from Taxus brevifolia. $\mathrm{J}$ Am Chem Soc, 1971; 93: 2325-7.

[209] Gueritte F. General and recent aspects of the chemistry and structure-activity relationships of taxoids. Curr Pharm Des, 2001; 7: 1229-49.

[210] Crown J, O'Leary M. The taxanes: an update. Lancet, 2000; 355: 1176-8.

[211] Rowinsky EK, Donehower RC. Paclitaxel (taxol). N Engl J Med, 1995; 332: 1004-14.

[212] Kavallaris M, Kuo DY, Burkhart CA, Regl DL, Norris MD, Haber M, Horwitz SB. Taxol-resistant epithelial ovarian tumors are associated with altered expression of specific beta-tubulin isotypes. $\mathbf{J}$ Clin Invest, 1997; 100: 1282-93.

[213] Derry WB, Wilson L, Jordan MA. Substoichiometric binding of taxol suppresses microtubule dynamics. Biochemistry, 1995; 34: 2203-11.

[214] Stearns ME, Wang M. Taxol blocks processes essential for prostate tumor cell (PC-3 ML) invasion and metastases. Cancer Res, 1992; 52: 3776-81.

[215] Toiyama Y, Inoue Y, Hiro J, Ojima E, Watanabe H, Narita Y, Okigami M, Hosono A, Miki C, Kusunoki M. Paclitaxel inhibits radiation induced VEGF secretion and enhances radiosensitizing effects in human colon cancer cell HT29. Cancer Ther, 2009; 7: 123-32.

[216] Galletti E, Magnani M, Renzulli ML, Botta M. Paclitaxel and docetaxel resistance: molecular mechanisms and development of new generation taxanes. ChemMedChem, 2007; 2: 920-42.

[217] Villeneuve DJ, Hembruff SL, Veitch Z, Cecchetto M, Dew WA, Parissenti AM. cDNA microarray analysis of isogenic paclitaxel- and doxorubicin-resistant breast tumor cell lines reveals distinct drug-specific genetic signatures of resistance. Breast Cancer Res Treat, 2006; 96: 17-39.

[218] Podolski-Renic A, Andelkovic T, Bankovic J, Tanic N, Ruzdijic S, Pesic M. The role of paclitaxel in the development and treatment of multidrug resistant cancer cell lines. Biomed Pharmacother, 2011; 65: 345-53.

[219] Ferreira MJ, Gyemant N, Madureira AM, Tanaka M, Koos K, Didziapetris R, Molnar J. The effects of jatrophane derivatives on the reversion of MDR1- and MRP-mediated multidrug resistance in the MDA-MB-231 (HTB-26) cell line. Anticancer Res, 2005; 25: 4173-8.

[220] Vasas A, Sulyok E, Redei D, Forgo P, Szabo P, Zupko I, Berenyi A, Molnar J, Hohmann J. Jatrophane diterpenes from Euphorbia esula as antiproliferative agents and potent chemosensitizers to overcome multidrug resistance. J Nat Prod, 2011; 74: 1453-61.

[221] Corea G, Fattorusso E, Lanzotti V, Taglialatela-Scafati O, Appendino G, Ballero M, Simon PN, Dumontet C, Di Pietro A. Jatrophane diterpenes as P-glycoprotein inhibitors. First insights of structure-activity relationships and discovery of a new, powerful lead. J Med Chem, 2003; 46: $3395-402$.

[222] Lu ZQ, Guan SH, Li XN, Chen GT, Zhang JQ, Huang HL, Liu X, Guo DA. Cytotoxic diterpenoids from Euphorbia helioscopia. J Nat Prod, 2008; 71: 873-6.

[223] Duarte N, Lage H, Ferreira MJ. Three new jatrophane polyesters and antiproliferative constituents from Euphorbia tuckeyana. Planta Med, 2008; 74: 61-8.

[224] Miglietta A, Gabriel L, Appendino G, Bocca C. Biological properties of jatrophane polyesters, new microtubule-interacting agents. Cancer Chemother Pharmacol, 2003; 51: 67-74.

[225] Schnabel C, Sterz K, Muller H, Rehbein J, Wiese M, Hiersemann M. Total synthesis of natural and non-natural Delta(5,6)Delta(12,13)-jatrophane diterpenes and their evaluation as MDR modulators. J Org Chem, 2011; 76: 512-22.

[226] Corea G, Di Pietro A, Dumontet C, Fattorusso E, V. L. Jatrophane diterpenes from Euphorbia spp. as modulators of multidrug resistance in cancer therapy. Phytochem Rev, 2009: 431-447.

[227] Aljancic IS, Pesic M, Milosavljevic SM, Todorovic NM, Jadranin M, Milosavljevic G, Povrenovic D, Bankovic J, Tanic N, Markovic ID, Ruzdijic S, Vajs VE, Tesevic VV. Isolation and biological evaluation of jatrophane diterpenoids from Euphorbia dendroides. J Nat Prod, 2011; 74: 1613-20.

[228] Pesic M, Bankovic J, Aljancic IS, Todorovic NM, Jadranin M, Vajs VE, Tesevic VV, Vuckovic I, Momcilovic M, Markovic ID, Tanic N, Ruzdijic S. New anti-cancer characteristics of jatrophane diterpenes from Euphorbia dendroides. Food Chem Toxicol, 2011; 49: 3165-73.

[229] Jadranin M, Pesic M, Aljancic IS, Milosavljevic SM, Todorovic NM, Podolski-Renic A, Bankovic J, Tanic N, Markovic I, Vajs VE, Tesevic VV. Jatrophane diterpenoids from the latex of 
Euphorbia dendroides and their anti-P-glycoprotein activity in human multi-drug resistant cancer cell lines. Phytochemistry, 2013; 86: 208-17.

[230] Podolski-Renic A, Jadranin M, Stankovic T, Bankovic J, Stojkovic S, Chiourea M, Aljancic I, Vajs V, Tesevic V, Ruzdijic S, Gagos S, Tanic N, Pesic M. Molecular and cytogenetic changes in multi-drug resistant cancer cells and their influence on new compounds testing. Cancer Chemother Pharmacol, 2013; 72: 683-97.

[231] Novakovic M, Pesic M, Trifunovic S, Vuckovic I, Todorovic N, Podolski-Renic A, Dinic J, Stojkovic S, Tesevic V, Vajs V, Milosavljevic S. Diarylheptanoids from the bark of black alder inhibit the growth of sensitive and multi-drug resistant non-small cell lung carcinoma cells. Phytochemistry, 2014; 97: 46-54.

[232] Dinic J, Novakovic M, Podolski-Renic A, Stojkovic S, Mandic B, Tesevic V, Vajs V, Isakovic A, Pesic M. Antioxidative activity of diarylheptanoids from the bark of black alder (Alnus glutinosa) and their interaction with anticancer drugs. Planta Med, 2014; 80: 1088-96.

[233] Dinic J, Randjelovic T, Stankovic T, Dragoj M, Isakovic A, Novakovic M, Pesic M. Chemoprotective and regenerative effects of diarylheptanoids from the bark of black alder (Alnus glutinosa) in human normal keratinocytes (in press). Fitoterapia, 2015.

[234] Hunyadi A, Martins A, Danko B, Chang F, Wu Y. Protoflavones: a class of unusual flavonoids as promising novel anticancer agents. Phytochemistry Reviews, 2014; 13: 69-77.

[235] Chen WY, Hsieh YA, Tsai CI, Kang YF, Chang FR, Wu YC, Wu CC. Protoapigenone, a natural derivative of apigenin, induces mitogen-activated protein kinase-dependent apoptosis in human breast cancer cells associated with induction of oxidative stress and inhibition of glutathione Stransferase pi. Invest New Drugs, 2011; 29: 1347-59.

[236] Nakagawa-Goto K, Chang PC, Lai CY, Hung HY, Chen TH, Wu PC, Zhu H, Sedykh A, Bastow KF, Lee KH. Antitumor agents. 280. Multidrug resistance-selective desmosdumotin B analogues. J Med Chem, 2010; 53: 6699-705.

[237] Szakacs G, Hall MD, Gottesman MM, Boumendjel A, Kachadourian R, Day BJ, BaubichonCortay H, Di Pietro A. Targeting the Achilles heel of multidrug-resistant cancer by exploiting the fitness cost of resistance. Chem Rev, 2014; 114: 5753-74.

[238] Stanković T, Balázs D, Martins A, Dragoj M, Stojković S, Isaković A, Wang H, Wu Y, Hunyadi A, Pešić M. Lower antioxidative capacity of multidrug resistant cancer cells confers collateral sensitivity to protoflavone derivatives (in press). Cancer Chemother Pharmacol, 2015.

[239] Leuschner C, Hansel W. Membrane disrupting lytic peptides for cancer treatments. Curr Pharm Des, 2004; 10: 2299-310.

[240] Bechinger B, Lohner K. Detergent-like actions of linear amphipathic cationic antimicrobial peptides. Biochim Biophys Acta, 2006; 1758: 1529-39.

[241] Chen YQ, Min C, Sang M, Han YY, Ma X, Xue XQ, Zhang SQ. A cationic amphiphilic peptide ABP-CM4 exhibits selective cytotoxicity against leukemia cells. Peptides, 2010; 31: 1504-10.

[242] Hammer MU, Brauser A, Olak C, Brezesinski G, Goldmann T, Gutsmann T, Andra J. Lipopolysaccharide interaction is decisive for the activity of the antimicrobial peptide NK-2 against Escherichia coli and Proteus mirabilis. Biochem J, 2010; 427: 477-88.

[243] Lohner K, Prenner EJ. Differential scanning calorimetry and X-ray diffraction studies of the specificity of the interaction of antimicrobial peptides with membrane-mimetic systems. Biochim Biophys Acta, 1999; 1462: 141-56.

[244] Zwaal RF, Schroit AJ. Pathophysiologic implications of membrane phospholipid asymmetry in blood cells. Blood, 1997; 89: 1121-32.

[245] Manno S, Takakuwa Y, Mohandas N. Identification of a functional role for lipid asymmetry in biological membranes: Phosphatidylserine-skeletal protein interactions modulate membrane stability. Proc Natl Acad Sci U S A, 2002; 99: 1943-8.

[246] Utsugi T, Schroit AJ, Connor J, Bucana CD, Fidler IJ. Elevated expression of phosphatidylserine in the outer membrane leaflet of human tumor cells and recognition by activated human blood monocytes. Cancer Res, 1991; 51: 3062-6.

[247] Schroder-Borm H, Bakalova R, Andra J. The NK-lysin derived peptide NK-2 preferentially kills cancer cells with increased surface levels of negatively charged phosphatidylserine. FEBS Lett, 2005; 579: 6128-34. 
[248] Pohl A, Lage H, Muller P, Pomorski T, Herrmann A. Transport of phosphatidylserine via MDR1 (multidrug resistance 1)P-glycoprotein in a human gastric carcinoma cell line. Biochem J, 2002; 365: 259-68.

[249] Bankovic J, Andra J, Todorovic N, Podolski-Renic A, Milosevic Z, Miljkovic D, Krause J, Ruzdijic S, Tanic N, Pesic M. The elimination of P-glycoprotein over-expressing cancer cells by antimicrobial cationic peptide NK-2: the unique way of multi-drug resistance modulation. Exp Cell Res, 2013; 319: 1013-27. 